\title{
Membrane distillation for concentration of hypersaline brines from the Great Salt Lake: Effects of scaling and fouling on performance, efficiency, and salt rejection
}

\author{
John A. Bush, Johan Vanneste, Tzahi Y. Cath* \\ Colorado School of Mines, Golden, CO, USA
}

*Corresponding author: email: tcath@mines.edu; phone: (303) 273-3402; fax: (303) 273-3413

A manuscript prepared for possible publication in

Separation and Purification Technology

April 2016 


\begin{abstract}
Membrane distillation (MD) is a thermally-driven separation process that utilizes a difference in vapor pressure across a porous, hydrophobic membrane as the driving force. MD may be applied to aqueous systems at concentrations up to and exceeding saturation of both sparingly soluble salts and soluble salts such as sodium chloride $(\mathrm{NaCl})$, leading to potential application in highrecovery desalination processes that approach Zero Liquid Discharge (ZLD) operation, or as a concentration strategy for mineral recovery. Scaling and fouling is a significant risk for such processes, and knowledge of the effects of these phenomena on performance is essential to the evaluation of MD as a viable technology for these applications. The present study investigated the scaling and fouling behavior of a hypersaline brine collected from the North Arm of the Great Salt Lake (GSL), which was nearly saturated with respect to $\mathrm{NaCl}$, and also contained high concentrations of dissolved minerals and organic carbon. Effects on water flux, thermal efficiency, and salt rejection were measured, and membranes used were analyzed before and after testing to evaluate potential causes of these effects. Scaling by $\mathrm{NaCl}$ crystallization on the membrane surface limited water recovery to approximately $10 \%$, and also caused damage to the internal pore structure of the membrane when the temperature difference $(\Delta T)$ between the feed and distillate was greater than $20^{\circ} \mathrm{C}$. Analysis of the solution chemistry of the GSL water was effective in predicting the scaling tendency of $\mathrm{NaCl}$, but inadequate in predicting the scaling tendency of other salts. Amorphous scaling structures on the membrane surfaces containing magnesium and oxygen were implied as the dominant factors contributing to performance decline at concentrations below $\mathrm{NaCl}$ saturation, and the result of fouling due to interactions between organic matter and magnesium. Operation at a maximum water recovery of $8 \%$ combined with intermittent reversal of the temperature gradient were effective strategies to prevent both scaling and fouling and maintain long-term performance.
\end{abstract}

\title{
Keywords:
}

Membrane distillation; desalination; hypersaline brine; membrane scaling; membrane fouling 


\section{Introduction}

Desalination technologies are increasingly becoming important for the treatment of impaired water for drinking, agriculture, diverse industries, and for environmental protection. Due to increased water demand, technological advancements, and improvements in the costcompetitiveness of desalination, it is currently in a period of rapid growth and is expected to reach a global capacity of 100 million $\mathrm{m}^{3} /$ day in 2015 [1]. Although desalination may be a promising means of meeting fresh water demands in water scarce regions, it is rather energy intensive and produces a hypersaline reject brine that presents an environmental disposal challenge. Concentrated brines from seawater desalination are typically returned to the sea. In the case of inland brackish water desalination, where disposal to seawater is not an option, the brine must be disposed of by other means, including land application, which may adversely impact soil and groundwater [2].

Strategies to reduce the volume of brine generated during desalination could greatly reduce the environmental impact of desalination, particularly if they include mineral recovery from brine and approach a zero liquid discharge (ZLD) operation. These brines may contain minerals of economic importance, which could offset the increased cost of desalination. Naturally occurring hypersaline brines such as the Great Salt Lake (GSL) and the Dead Sea [3] are already utilized commercially for recovery of minerals composed of the most concentrated ions, including sodium, potassium, calcium, magnesium, sulfate, and chloride. Mineral extraction from lower salinity brines has also been explored, including from some geothermal brines [4-6] and desalination brines [7]. Some brines have also attracted interest as a source of higher value minerals such as lithium [8-11]. However, most brines are composed primarily of common salts such as sodium chloride $(\mathrm{NaCl})$, and concentration combined with salt removal is needed before the more valuable minerals can be recovered. This initial concentration is often accomplished using evaporation ponds that require large amounts of land area and time for evaporation, lose large amounts of water to the atmosphere, and experience seasonal variation in performance due to local climate conditions.

Separation processes that can desalinate water containing very high total dissolved solids (TDS) could potentially increase water recovery while serving as the primary concentration process for mineral recovery, which may improve overall process efficiency and reduce the footprint of combined desalination and mineral recovery operations. However, due to both 
inherent thermodynamic and physical limitations and high mineral scaling potential, high recovery desalination is difficult to achieve with existing technologies. Thermal desalination such as multi-stage flash distillation (MSF) and multiple-effect distillation (MED) are prone to mineral scaling of heat exchanger surfaces due to the high temperatures involved, and therefore they typically operate in the range of 10-30\% water recovery for seawater desalination [12]. Reverse osmosis (RO) may achieve higher recovery, typically about 50\% for seawater; however, it is also susceptible to organic and biological fouling [13, 14] and experiences increasing energy demand with recovery due to the increased osmotic pressure of the feed solution as it is concentrated. Moreover, as concentration increases, the hydraulic pressure required to overcome the osmotic pressure eventually exceeds the mechanical limitations of the membranes and modules used, effectively restricting the maximum operating concentration.

Membrane distillation (MD) is a unique membrane process that utilizes a partial vapor pressure difference across a hydrophobic, microporous membrane to induce vapor transport through the membrane pores [15]. The most common configuration, known as direct contact membrane distillation (DCMD), involves both the feed solution and distillate in direct contact with the two membrane surfaces, and vapor pressure difference is established by maintaining the feed solution at a higher temperature than the distillate. In principle, mass transport occurs in the vapor phase only, allowing for the separation of highly purified water from brines containing primarily nonvolatile solutes such as those present in seawater, brackish groundwater, or saline lake water. Because the feed solution and distillate are separated by a vapor phase, the difference in osmotic pressure between the feed and permeate streams does not affect the process; and because the partial vapor pressure of water is only slightly affected by the presence of dissolve ions, very high salinity streams can be desalinated with MD. Only minimal flux decline is observed when using MD to desalinate water having high $\mathrm{NaCl}$ concentrations [16-19], and because of this, MD is believed to have great potential as a desalination process for brines, including concentrates from RO [20-24] and nanofiltration (NF) [25-27], and hypersaline streams such as water from the GSL [28].

The unique capabilities of MD at high salt concentrations have led to interest in its potential for integration with crystallization and mineral recovery in a combined membrane distillation crystallization (MDC) process, and has been effectively demonstrated at the laboratory scale for the recovery of various salts commonly found in natural and industrial brines, including $\mathrm{NaCl}$ 
[25, 29-32], $\mathrm{CaCO}_{3}$ and $\mathrm{MgSO}_{4}$ [25], and $\mathrm{Na}_{2} \mathrm{SO}_{4}$ [26, 32]. For the most part, efforts to date have used synthetic solutions, which may perform quite differently than natural brines. For example, in an MDC study using RO concentrate from natural seawater, Ji et al. [20] reported reduced transmembrane flux, a $20 \%$ reduction of salts crystallized, and a $15-23 \%$ reduction in crystal growth rate (compared to artificial concentrates) due to dissolved organic matter.

As in other desalination processes, mineral scaling and organic fouling may be significant problems for MD, and the potential for MDC to become established as a viable treatment strategy is in part dependent on a more comprehensive understanding of crystallization behavior of natural hypersaline brines concentrated with MD. Scaling by sparingly soluble salts such as $\mathrm{CaCO}_{3}, \mathrm{CaSO}_{4}$, and silica [33-38] are known to cause substantial flux decline. However, in some cases it has been shown that the scale layer formed on the feed side of MD membranes is relatively porous and does not completely prevent water flux [37] and may be removed with simple cleaning processes [28, 35, 39]. Also, employing management strategies such as periodic flushing of the membrane with DI water [36] or periodic reversal of the driving force, which reverses the direction of water transport [28], can interrupt the crystallization process before sufficient induction time has passed and may mitigate scale formation. While scaling by sparingly soluble salts typically forms on the membrane surface only and does not affect salt rejection, scaling by $\mathrm{NaCl}$ on the membrane surface itself has been shown to aggravate pore wetting [29, 39], which reduces water flux due to the loss of driving force and can also reduce salt rejection, and may lead to crystallization inside the pores themselves [30]. Crystallization on membrane surfaces may also affect membrane properties such as surface hydrophobicity and mechanical strength [40].

In this study we investigated scaling and fouling behavior of the MD process applied to the concentration of hypersaline brine obtained from the North Arm of the GSL, which is nearly saturated with respect to $\mathrm{NaCl}$ and contains high concentrations of calcium, magnesium, potassium, sulfate, silica, and natural organic matter. Experiments and analyses were performed to isolate the effects of scaling by the different salts at high concentration factors, to identify dominant scaling and fouling mechanisms, and to characterize the short-term and long-term effects on membrane performance. Strategies for preventing and mitigating these effects were also investigated. 


\section{Mass and heat transfer in MD}

Water flux $(J)$ in the MD process is proportional to the vapor pressure difference between the feed and distillate streams [41]:

$$
J=C_{\mathrm{m}}\left(p_{\mathrm{f}, \mathrm{m}}-p_{\mathrm{d}, \mathrm{m}}\right)
$$

where $p_{\mathrm{f}, \mathrm{m}}$ and $p_{\mathrm{d}, \mathrm{m}}$ are the vapor pressures of the feed and distillate streams at the membrane surface, respectively, and $C_{\mathrm{m}}$ is a mass transfer coefficient that is characteristic of the system. $C_{\mathrm{m}}$ is a function of the membrane physical properties (i.e., thickness, porosity, pore size, and pore tortuosity), and the temperature and pressure of the gaseous phase within the pores. In the DCMD configuration, vapor pressure differential is accomplished by maintaining a higher feed stream temperature $\left(T_{\mathrm{f}}\right)$ than distillate stream temperature $\left(T_{\mathrm{d}}\right)$. For pure water or very dilute solutions, vapor pressure of water at the membrane surface is a function of the mean membrane temperature $\left(T_{\mathrm{m}}\right)$ in accordance to the Antoine equation:

$$
p=\exp \left(23.238-\frac{3841}{T_{\mathrm{m}}-45}\right)
$$

where $T_{\mathrm{m}}=\left(T_{\mathrm{f}}+T_{\mathrm{d}}\right) / 2$. At relatively low temperature difference between the feed and distillate streams, water flux may be expressed as a function of temperature:

$$
J=C_{\mathrm{m}} \frac{d p}{d T} \Delta T
$$

where $\Delta T=T_{\mathrm{f}}-T_{\mathrm{d}}$ and with $d p / d T$ approximated using the Clausius-Claperyon relation evaluated at $T_{\mathrm{m}}$ :

$$
\left.\frac{d p}{d T}\right|_{T_{\mathrm{m}}}=\frac{p \Delta H_{\mathrm{vap}} M}{R T_{\mathrm{m}}^{2}}
$$

where $\Delta H_{\text {vap }}$ is the latent enthalpy of vaporization evaluated at $T_{\mathrm{m}}, M$ is the molecular weight of water, and $R$ is the universal gas constant. From equations (2) and (4) it can be seen that $d p / d T$ increases with $T_{\mathrm{m}}$, leading to an exponential relationship between water flux and $\Delta T$.

The driving force in MD is negatively affected by salinity due to the reduction of vapor pressure caused by the presence of dissolved ions, which reduce the water activity of the solution. The associated reduction of water flux can be substantial; theoretical water flux in pure $\mathrm{NaCl}$ solutions approaching saturation concentration may be as little as $50 \%$ compared to pure water flux for similar operating conditions $[42,43]$.

Mass transfer in MD is a function of the vapor pressure, and hence the temperature and concentration, at the membrane surface and not the bulk fluid. Heat transfer in the MD process 
occurs primarily by conduction and by bulk transport as the water vapor carries the energy associated with latent enthalpy of vaporization through the membrane. Both mechanisms of heat transfer contribute to temperature polarization due to the development of a thermal boundary layer between both membrane surfaces and the bulk fluid in each flow channel, resulting in a lower $\Delta T$ between the membrane surfaces than the bulk $\Delta T$.

The heat transport associated with mass transport is a necessary consequence of the process; however, the conductive heat transfer does not serve a useful purpose and is considered a loss. Thermal efficiency $\left(\eta_{\mathrm{th}}\right)$ of the MD process is defined as the ratio of heat transfer associated with mass transfer to the total heat transfer [44]:

$$
\eta_{\text {th }}=\frac{Q_{\text {vap }}}{Q_{\text {vap }}+Q_{\text {cond }}}
$$

where $Q_{\text {vap }}$ is the heat transfer resulting from the vapor transport across the membrane and $Q_{\text {cond }}$ is the heat transfer due to conduction through the membrane.

Thermal efficiency is primarily considered a property of the membrane; however, increasing $\Delta T$ increases thermal efficiency [42], as does increasing $T_{\mathrm{m}}$ for similar $\Delta T$. This is because the driving force and water flux increase exponentially with $\Delta T$ whereas the conduction heat transfer rate increases linearly with $\Delta T$. Experimentally, thermal efficiency may be measured if temperature of the water and the flow rates at the inlets and outlets of the flow channels are known. Because energy is conserved, the total heat transfer across the membrane is equal to the enthalpy change between the inlet and outlet of either the feed or distillate stream. To minimize the error due to heat loss through the flow cell, thermal efficiency in this study was calculated using the enthalpy change of the distillate stream, as expressed in the following:

$$
\eta_{\text {th }}=\frac{\dot{m}_{\mathrm{m}} \Delta H_{\mathrm{vap}}}{c_{\mathrm{p}}\left[\left(\dot{m}_{\mathrm{d}}+\dot{m}_{\mathrm{m}}\right) T_{\mathrm{d}, \mathrm{out}}-\dot{m}_{\mathrm{d}} T_{\mathrm{d}, \mathrm{in}}\right]}
$$

where $\dot{m}_{\mathrm{m}}$ is the mass flow rate of water vapor through the membrane, $\dot{m}_{\mathrm{d}}$ is the mass flow rate of the distillate stream, $T_{\mathrm{d}, \text { in }}$ and $T_{\mathrm{d} \text {,out }}$ are the distillate temperature at the inlet and outlet of the channel, respectively, and $c_{\mathrm{p}}$ is the constant-pressure specific heat of pure water.

Because mass transfer occurs in the vapor phase, MD provides very high rejection of nonvolatile solutes; however, solute transport can and does still occur if liquid water floods the membrane pores. In this case, it is assumed that the membrane does not selectively reject dissolved solids due to the large pore size; therefore, solute rejection may be calculated using the change in volume and conductivity of the distillate and feed streams over time: 


$$
\text { Salt rejection }(\%)=\left(1-\frac{V_{\mathrm{d} 2} \sigma_{\mathrm{d} 2}-V_{\mathrm{d} 1} \sigma_{\mathrm{d} 1}}{\left(V_{\mathrm{d} 2}-V_{\mathrm{d} 1}\right) \sigma_{\mathrm{f}}}\right) \times 100
$$

where $\sigma_{\mathrm{f}}$ and $\sigma_{\mathrm{d}}$ are the conductivities of the feed and distillate solutions, and $V_{\mathrm{d} 1}$ and $V_{\mathrm{d} 2}$ represent the total volume of the distillate system at times 1 and 2 across a time interval.

\section{Materials and Methods}

\subsection{Solution chemistry and analytical methods}

Concentration and scaling experiments were performed primarily with brine collected from the North Arm of the GSL as the feed solution, and deionized water as the distillate stream. Additional experiments were performed with synthetic solutions of ACS grade $\mathrm{NaCl}$ for comparison with the results from the GSL brine experiments. The raw GSL brine was prefiltered through a 0.5 micron cartridge filter to remove suspended solids, and analyzed for dissolved solids according to Standard Methods [45]. Alkalinity was determined with a digital titrator test kit (Model 16900-01, Hach Co., Loveland, CO) using $1.6 \mathrm{~N} \mathrm{H}_{2} \mathrm{SO}_{4}$ as titrant. Total organic carbon was determined using the combustion catalytic oxidation method (Model TOC-L, Shimadzu Corp., Kyoto, Japan). Water samples were diluted and filtered through a 0.45 micron filter and analyzed for anions with an ion chromatograph (Model ICS-90, Dionex, Sunnyvale, CA) and for cations with an inductively coupled plasma atomic emission spectrometer (ICSAES) (Optima 5300 DV, PerkinElmer Inc., Waltham, MA).

OLI Stream Analyzer (OLI systems Inc., Cedar Knolls, NJ) was used to estimate the scaling

tendency of the GSL brine at increased concentration. Stream Analyzer utilizes the OLI aqueous thermodynamic engine, and calculates scaling tendency as the ratio of the solution solubility product to the thermodynamic limit based on the thermodynamic equilibrium constant, also known as the saturation ratio.

\subsection{Membranes and modules}

Hydrophobic, microporous membrane acquired from GE Water (Minnetonka, MN) was tested in this study. The membrane used is a symmetric, isotropic membrane made from polypropylene, and have a nominal pore size of $0.22 \mu \mathrm{m}$, porosity of approximately $70 \%$, thickness of approximately $150 \mu \mathrm{m}$, and a pure water contact angle of $122^{\circ}$. Two different flow cells were used in the investigation, both made of acrylic plastic. Cell 1 was a SEPA cell 
modified for DCMD operation, and Cell 2 was a custom-made flow cell fitted with a glass window on the feed side to allow observation of the membrane surface during experiments. Spacers were used in both the feed and distillate channels of the cell with a filament diameter of $2.3 \mathrm{~mm}$, mesh length of $16 \mathrm{~mm}$, mesh width of $10.8 \mathrm{~mm}$, and hydrodynamic angle of $70^{\circ}$. Each flow cell was fitted with four Type-T thermocouples, located at the inlets and outlets of the feed and distillate channels.

The physical dimensions of the flow cell channels are summarized in Table 1, where membrane surface area, $A_{\mathrm{s}}$ is equal to the length $l$ multiplied by the width $w$ of the flow channel. Hydraulic diameter $D_{H}$ for a spacer-filled channel is defined as [46]:

$$
D_{H}=\frac{4 \varepsilon}{\frac{2}{h}+(1-\varepsilon) S_{V, S P}}
$$

where $\varepsilon$ is the spacer porosity and $S_{V, S P}$ is the specific surface area of the spacer:

$$
\begin{aligned}
& \varepsilon=1-V_{S P} / V_{\text {tot }} \\
& S_{V, S P}=\frac{S_{S P}}{V_{S P}}=\frac{\pi[D l]_{\text {filament }}}{\frac{\pi}{4}\left[D^{2} l\right]_{\text {filament }}}=\frac{4}{D_{\text {filament }}}
\end{aligned}
$$

Effective cross-section flow area of the channel is defined as:

$$
A_{\mathrm{c}, \mathrm{eff}}=h w \varepsilon
$$

\begin{tabular}{|c|c|c|c|c|c|c|}
\hline Cell & $\begin{array}{c}\text { Flow channel } \\
\text { length } \\
l(\mathrm{~mm})\end{array}$ & $\begin{array}{c}\text { Flow channel } \\
\text { width } \\
w(\mathrm{~mm})\end{array}$ & $\begin{array}{c}\text { Flow channel } \\
\text { height } \\
h(\mathrm{~mm})\end{array}$ & $\begin{array}{c}\text { Membrane } \\
\text { surface area } \\
A_{\mathrm{s}}\left(\mathrm{cm}^{2}\right)\end{array}$ & $\begin{array}{c}\text { Channel cross } \\
\text { section } \\
A_{\mathrm{c}, \mathrm{eff}}\left(\mathrm{cm}^{2}\right)\end{array}$ & $\begin{array}{c}\text { Channel hydraulic } \\
\text { diameter } \\
D_{H}(\mathrm{~cm})\end{array}$ \\
\hline 1 & 145 & 94 & 2.5 & 136 & 1.979 & 0.2758 \\
\hline 2 & 212 & 40 & 3 & 85 & 1.042 & 0.3413 \\
\hline
\end{tabular}

Table 1. Physical dimensions of experimental flow cell channels. Cell 1 was a SEPA Cell modified for DCMD, Cell 2 was a custom-made flow cell fitted with a glass observation window on the feed side.

\subsection{Bench-scale system description}

An automated, closed-loop, bench-scale membrane testing system was used to evaluate the performance of the membranes in the DCMD process. Data acquisition and system controls were accomplished using LabVIEW (National Instruments, Austin, TX) software on a Windows PC using a DAC device (Model U6, LabJack Corporation, Lakewood, CO). A detailed schematic of the experimental system is presented in Fig. 1.

The MD system provided heating and cooling to both feed and distillate streams, which were pumped continuously during operation using positive-displacement gear pumps (Micropump 
Integral Series, IDEX Corp. Vancouver, WA). The feed solution was heated directly using a 1500 W electric immersion heater (Model 1019, Hotwatt, Danvers, MA). Heat exchangers supplied with hot and cold glycol solutions were used to control the temperature of the distillate. Feed solution temperature was maintained by intermittent operation of the electric heater and distillate temperature was maintained by adjusting the flow rates of the glycol solutions using proportional valves. Heater duty cycle and valve position were controlled using a PID algorithm in the LabVIEW code with the feed temperature $\left(T_{\mathrm{f}}\right)$ and distillate temperature $\left(T_{\mathrm{d}}\right)$ as process variables, both measured at the inlet of the flow cell. For experiments involving reversal of the temperature gradient, an additional heat exchanger installed in the feed loop was supplied with the cold glycol solution to maintain the desired temperature of the feed solution.

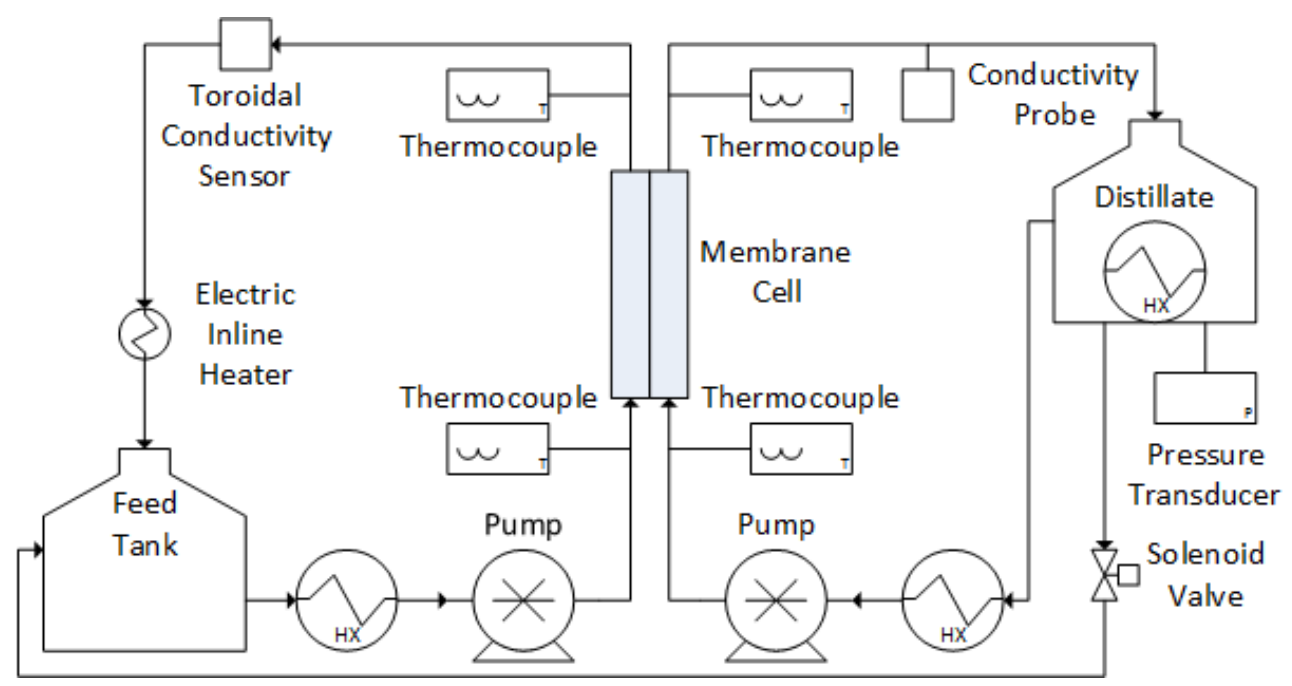

Fig. 1. Flow schematic of the bench-scale MD system used in the study. Feed and distillate streams were recirculated on their respective closed loop at $1.6 \mathrm{~L} / \mathrm{min}$. Accumulated distillate was intermittently returned to the feed tank through a bypass line. Temperatures were measured at the inlets and outlets of the membrane test cell and were used to both monitor and control the streams temperatures.

Conductivity of both the feed and distillate solutions were continuously monitored and recorded to estimate the concentration of the feed solution and to calculate salt rejection by the membrane. Feed conductivity was monitored using a toroidal sensor (Model TCSMA, Sensorex, Garden Grove, CA) and conductivity of the distillate was monitored using a dip style conductivity probe (Model T-35820-62, Cole-Parmer, Vernon Hills, IL) installed in the return line. 
Water flux was calculated using the measured change in mass of the distillate in a cylindrical acrylic tank, which was equipped with a pressure transducer installed near the bottom of the tank to measure the height of the water column. The distillate tank was also fitted with a solenoid valve connected to a return line to the feed tank, allowing the collected distillate to be periodically drained back to the feed tank during operation.

\subsection{Membrane performance experiments}

For each set of experiments, a new membrane coupon was cut from dry flat sheets and installed into the membrane cell. The feed and distillate solutions were then pumped through the system at the desired flow rate and adjusted to the desired temperature. During the warm-up period the initial concentration was maintained constant by returning any collected distillate to the feed tank. All experiments were performed using co-current flow to minimize local pressure differential across the membrane at the channel entrances and exits due to pressure drop through the channels. For all experiments, both feed and distillate flow rates were kept constant at $1.6 \mathrm{~L}$ $\min ^{-1}$, corresponding to a bulk channel velocity of $13 \mathrm{~cm} \mathrm{~s}^{-1}$ for Cell 1 and $25 \mathrm{~cm} \mathrm{~s}^{-1}$ for Cell 2 , based on the effective cross-section flow area, $A_{\mathrm{c}, \text { eff. }}$

\subsubsection{Baseline performance experiments}

To establish a reference for comparison with brine concentration, experiments were performed using a dilute solution of $\mathrm{NaCl}$. The $\mathrm{NaCl}$ was added at a low concentration to determine salt rejection without substantially affecting water flux. These experiments used $3 \mathrm{~L}$ of $1 \mathrm{~g} \mathrm{~L}^{-1} \mathrm{NaCl}$ for the feed, and $3 \mathrm{~L}$ of deionized water for the initial distillate stream. Both flow cells were tested with $T_{\mathrm{f}}$ of $30^{\circ} \mathrm{C}$ to $70{ }^{\circ} \mathrm{C}$ and $T_{\mathrm{d}}$ of $20^{\circ} \mathrm{C}$ or $30^{\circ} \mathrm{C}$.

\subsubsection{NaCl concentration and scaling experiments}

Experiments were performed with synthetic solutions to characterize the effects of feed concentration and scaling by pure $\mathrm{NaCl}$ on the performance and durability of the membrane in the absence of other fouling agents. These experiments used Cell 1 and $4 \mathrm{~L}$ of a $200 \mathrm{~g} \mathrm{~L}^{-1} \mathrm{NaCl}$ solution maintained at either $50{ }^{\circ} \mathrm{C}$ or $70{ }^{\circ} \mathrm{C}$, concentrated with the distillate maintained at constant $30{ }^{\circ} \mathrm{C}$ until water flux ceased due to scaling of the membrane surface or the conductivity 
of the distillate exceeded $2000 \mu \mathrm{S} \mathrm{cm}^{-1}$ due to wetting of the membrane pores. Once either of these conditions occurred, the collected distillate was returned to the feed tank to dilute the solution to its initial concentration. This concentration and dilution cycle was repeated four times over the course of each experiment.

\subsubsection{North Arm GSL concentration and scaling experiments}

Performance and limitations of the MD process for the concentration of North Arm GSL brine were investigated with a series of experiments. Scaling behavior at high concentration, and the effects of scaling and fouling on long-term performance were also investigated. Initial concentration experiments were conducted with $T_{f}$ of $50{ }^{\circ} \mathrm{C}$ and $T_{d}$ of $30{ }^{\circ} \mathrm{C}$ until water flux ceased due to scaling to determine the practical limit of water recovery. These experiments were performed using Cell 2 to allow observation of scaling behavior using an optical microscope during the process.

Various scaling and fouling behaviors and long-term effects on performance were evaluated by repeated scaling and dilution cycles at different operating temperatures and water recovery. To investigate the effects of scaling of the membrane at high concentration factors, a series of experiments were performed using Cell 1 with constant $T_{\mathrm{f}}$ of $50{ }^{\circ} \mathrm{C}$ or $70{ }^{\circ} \mathrm{C}$ and constant $T_{\mathrm{d}}$ of $30{ }^{\circ} \mathrm{C}$. Concentration was allowed to proceed until severe scaling reduced the water flux to below $50 \%$ of the initial rate before the collected distillate was returned to the feed tank to dilute the brine to its original concentration. Potential scaling and fouling behavior by contaminants other than $\mathrm{NaCl}$ were investigated by repeated concentration cycles with water recovery limited to $8 \%$. These experiments were performed using Cell 2 with constant $T_{\mathrm{f}}$ of $50{ }^{\circ} \mathrm{C}$ and constant $T_{\mathrm{d}}$ of $30^{\circ} \mathrm{C}$.

A recent study found that intermittent reversal of the temperature gradient is an effective method to mitigate gradual flux decline in a DCMD process for the concentration of South Arm GSL brine [28], which has a similar composition as the North Arm GSL brine although at much lower concentrations. The effectiveness of this method was tested in the present study by first concentrating the North Arm GSL brine at $T_{\mathrm{f}}$ of $50{ }^{\circ} \mathrm{C}$ with $T_{\mathrm{d}}$ of $30{ }^{\circ} \mathrm{C}$ using Cell 2 . Once $8 \%$ recovery was reached, the collected distillate was returned to the feed tank. However, before each subsequent concentration cycle the feed was temporarily changed to a separate feed source of GSL brine maintained at $20{ }^{\circ} \mathrm{C}$ while continuing to maintain the distillate temperature at 30 
${ }^{\circ} \mathrm{C}$. Two different approaches to this method were tested: reverse temperature operation for a fixed time period of 5 minutes between each concentration cycle, and reverse temperature operation for a variable time period until stable reverse water flux was observed.

\subsection{Membrane characterization}

Upon completion of scaling experiments, the membranes were removed from the flow cells, air dried, and stored for further analysis. Characterization of the surface scale layer morphology and composition were accomplished using low-vacuum scanning electron microscopy (SEM) and energy dispersive x-ray spectroscopy (EDS) (Quanta 600, FEI Corp., Hillsboro, OR). The effects of the process on membrane structure and salt penetration were also investigated by observing the membrane cross-section at various locations. To ensure that the cutting process did not damage the internal structure of the membrane, an ethanol cryofracture procedure was utilized to produce the membrane samples for cross-section analysis. The membranes were first submerged in ethanol until the membrane and pores were completely flooded. The samples were then submerged in liquid nitrogen and cut with a razor blade, then removed from the liquid nitrogen and dried. All samples analyzed with the SEM were prepared with a gold sputtering using ionized argon gas.

Contact angle was measured after experiments were completed to investigate the effects on membrane hydrophobicity using the sessile drop method. Each membrane sample was prepared by taping flat to a microscope slide and analyzed using a Standard Goniometer (Model 200-00, Ramé-Hart Instrument, CO, Succasunna, NJ). Five $100 \mu \mathrm{L}$ drops of pure water were then placed on different locations of the sample, and 10 measurements were taken of each drop to determine an overall contact angle for the sample.

\section{Results and Discussion}

\subsection{Brine characterization}

The water of the GSL is a concentrated brine containing primarily sodium, potassium, magnesium, chloride, and sulfate ions with low alkalinity [47]. The primary sources of the GSL, a terminal lake that has no outlet other than evaporation, are rivers, precipitation, and hydrothermal springs. Due to its large size, shallow depth, and location in an arid climate, its size and composition fluctuate considerably with changes in precipitation and inflow. The completion 
of the Southern Pacific Railroad (SPRR) causeway in 1959 effectively divided the lake into two distinct sections, referred to as the North Arm and the South Arm [48]. Because the causeway severely inhibits mixing between the two sections, and the fact that more than $90 \%$ of the total freshwater inflow is received by the South Arm, the North Arm is considerably more concentrated than the South Arm, and has remained at or very close to saturation since 1960 [49]. The lake sediments contain substantial amounts of $\mathrm{CaCO}_{3}$, and the concentration of calcium in the lake remains more or less constant despite fluctuations in the lake inflow due to precipitation and dissolution of carbonate species [50].

The water collected for use in the present study was found to contain dissolved inorganic constituents typical of North Arm GSL brine and was also high in organic matter (Table 2). At standard temperature of $25^{\circ} \mathrm{C}$ and 1 atm pressure, the OLI simulation determined the GSL brine to be supersaturated with respect to silica and $\mathrm{CaCO}_{3}$, and very close to saturation concentration of $\mathrm{NaCl}$. The predicted concentration factor to reach $\mathrm{NaCl}$ saturation was 1.05 at $25{ }^{\circ} \mathrm{C}$, increasing to 1.07 and 1.10 for $50{ }^{\circ} \mathrm{C}$ and $70{ }^{\circ} \mathrm{C}$, respectively. Silica solubility increases with temperature and was found to exist below saturation at elevated temperature. Other salts with potential for scaling were $\mathrm{CaSO}_{4}$ (anhydrite), gypsum, $\mathrm{Mg}(\mathrm{OH})_{2}$, and $\mathrm{MgCO}_{3}$, particularly at elevated temperatures.

Table 2. Composition of the brine from the North Arm of the Great Salt Lake.

\begin{tabular}{|l|r|}
\hline Composition & $\begin{array}{l}\text { Concentration } \\
(\mathrm{mg} / \mathrm{L})\end{array}$ \\
\hline Lithium, $\mathrm{Li}^{+}$ & 43.6 \\
\hline Sodium, $\mathrm{Na}^{+}$ & 100,816 \\
\hline Potassium, $\mathrm{K}^{+}$ & 5517 \\
\hline Calcium, $\mathrm{Ca}^{2+}$ & 352 \\
\hline Magnesium, $\mathrm{Mg}^{2+}$ & 9381 \\
\hline Strontium, $\mathrm{Sr}^{2+}$ & 3.26 \\
\hline Chloride, $\mathrm{Cl}^{-}$ & 181,940 \\
\hline Bromide, $\mathrm{Br}^{-}$ & 127 \\
\hline Sulfate, $\mathrm{SO}_{4}{ }^{2-}$ & 19,727 \\
\hline Boron, $\mathrm{B}$ & 25.3 \\
\hline Silica, $\mathrm{SiO}{ }_{2}$ & 102 \\
\hline Alkalinity $($ as CaCO & \\
\hline Total dissolved solids & 278 \\
\hline Total organic carbon (TOC) & 344,000 \\
\hline pH & 87.1 \\
\hline
\end{tabular}




\subsection{Baseline performance}

Water flux and thermal efficiency as a function of the difference between the bulk feed and distillate temperature $(\Delta T)$ are shown in Fig. 2 for the two different flow cells and distillate temperature $\left(T_{\mathrm{d}}\right)$ of $20{ }^{\circ} \mathrm{C}$ or $30{ }^{\circ} \mathrm{C}$. For most of the operating conditions tested, particularly at higher $\Delta T$, measured flux was slightly higher for the Cell 1 than Cell 2 and thermal efficiency was slightly lower. In all cases, water flux increased exponentially with $\Delta T$, and measured values were similar to those reported in a previous study using the same membrane in a similar configuration [28]. As expected per the discussion in Section 2 regarding the relationship between $d P / d T$ and $T_{\mathrm{m}}$, the exponential relationship between $\Delta T$ and water flux was more pronounced at $T_{\mathrm{d}}$ of $30^{\circ} \mathrm{C}$. Thermal efficiencies were also higher with $T_{\mathrm{d}}$ of $30^{\circ} \mathrm{C}$ for similar $\Delta T$. Calculated salt rejection was greater than $99.8 \%$ for all operating conditions.
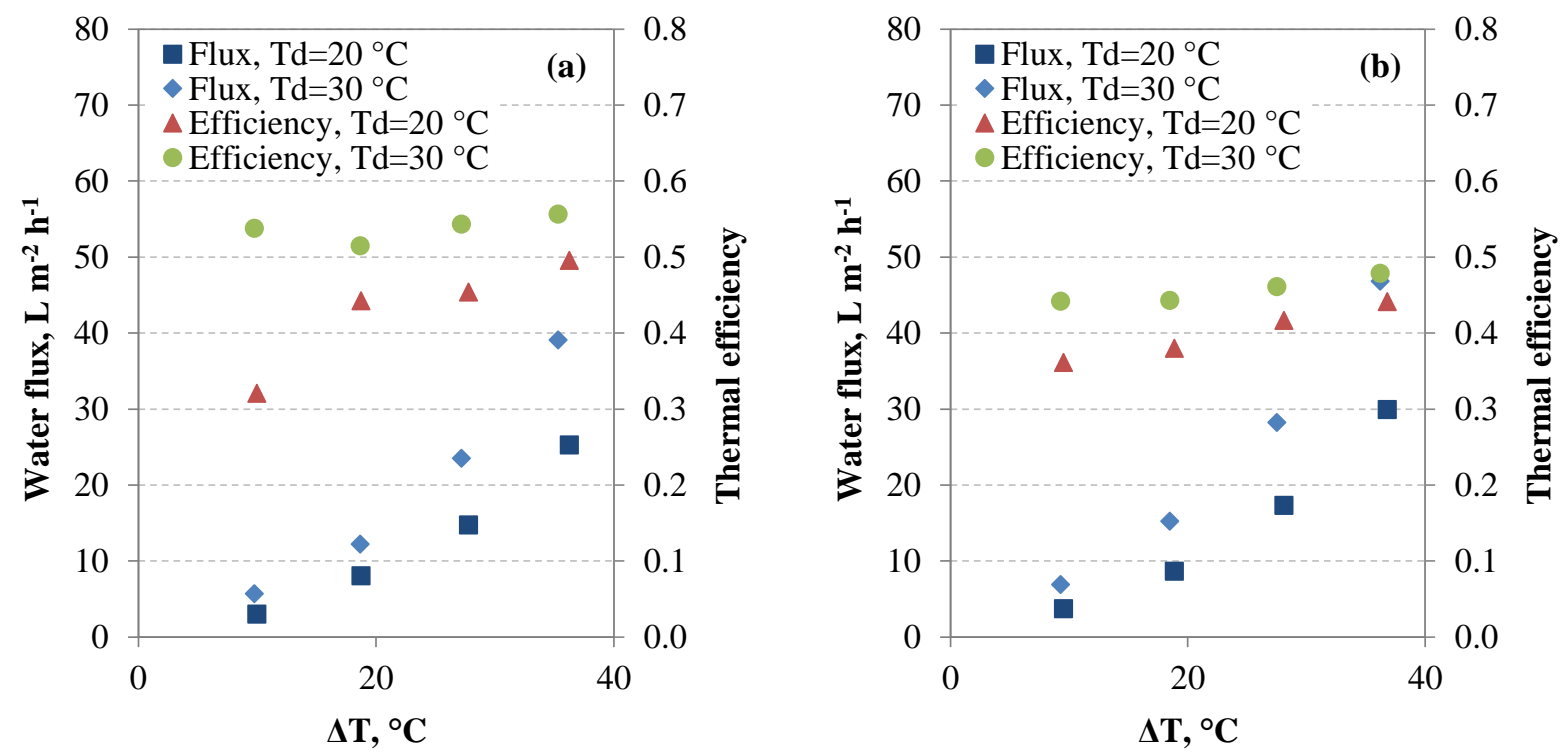

Fig. 2. Measured water flux and thermal efficiency for (a) Cell 1 and (b) Cell 2 tested with $1 \mathrm{~g} / \mathrm{L}$ $\mathrm{NaCl}$ feed solution and deionized water distillate stream. Feed temperatures $\left(T_{\mathrm{f}}\right)$ of $30-70{ }^{\circ} \mathrm{C}$ and distillate temperatures $\left(T_{\mathrm{d}}\right)$ of $20-30{ }^{\circ} \mathrm{C}$ were measured at the channel inlets. Flow rates for both feed and distillate were $1.6 \mathrm{~L} \mathrm{~min}^{-1}$ using co-current flow configuration, corresponding to crossflow velocity of $13 \mathrm{~cm} \mathrm{~s}^{-1}$ for Cell 1 and $25 \mathrm{~cm} \mathrm{~s}^{-1}$ for Cell 2 .

The differences in performance between the two flow cells may be a result of reduced temperature polarization effects in Cell 2 at the experimental flow rate, due to its smaller flow area and increased crossflow velocity. Reynolds numbers were substantially larger at increased 
temperatures due to the reduced viscosity of the feed water, and were 600-1100 for Cell 1 and 1000-1800 for Cell 2. The lower thermal efficiencies in Cell 2 for similar conditions were unexpected because thermal efficiency generally increases with flow velocity [42].

\subsection{Effects of scaling with pure $\mathrm{NaCl}$}

To characterize the effects of $\mathrm{NaCl}$ scaling on the membrane used in this study, a solution of $200 \mathrm{~g} \mathrm{~L}^{-1} \mathrm{NaCl}$ was concentrated using Cell 1 until water flux ceased due to scaling of the membrane surface, which was visible during testing due to the transparency of the acrylic flow cells used. Because thermal efficiency increases with overall temperature (Fig. 2), the $\mathrm{NaCl}$ concentration experiments were performed with constant $T_{\mathrm{d}}$ of $30{ }^{\circ} \mathrm{C}$ and constant $T_{\mathrm{f}}$ of $50{ }^{\circ} \mathrm{C}$ or $70{ }^{\circ} \mathrm{C}$. During these experiments, the solution was concentrated, then diluted by returning the collected distillate back to the feed tank, then concentrated again for a total of four concentration cycles.

Both water flux and thermal efficiency were very consistent over multiple concentration cycles for experiments performed with $T_{\mathrm{f}}$ of $50{ }^{\circ} \mathrm{C}$, as depicted in Fig. 3a. Water flux at feed concentration of $200 \mathrm{~g} \mathrm{~L}^{-1} \mathrm{NaCl}$ was approximately $10 \mathrm{~L} \mathrm{~m}^{-2} \mathrm{~h}^{-1}$, even after multiple scaling events - close to $82 \%$ of the water flux when operating with deionized water feed at similar conditions. Water flux declined steadily to $\sim 7.5 \mathrm{~L} \mathrm{~m}^{-2} \mathrm{~h}^{-1}$ over the course of each cycle up to a feed concentration of approximately $330 \mathrm{~g} \mathrm{~L}^{-1}$, or close to $62 \%$ of the water flux when operating with deionized water feed at similar conditions. No scaling was observed below a concentration of $330 \mathrm{~g} \mathrm{~L}^{-1}$ and salt rejection remained higher than $99.9 \%$ throughout all concentration cycles. Therefore, it can be concluded that the decline in water flux was due to the effects of reduced water activity at increased salinity. Above $330 \mathrm{~g} \mathrm{~L}^{-1} \mathrm{NaCl}$ feed concentration the water flux declined rapidly to zero as a result of membrane scaling.

Curiously, thermal efficiency was not strongly affected by the increased concentration, and the measured thermal efficiency of $\sim 54 \%$ at $200 \mathrm{~g} \mathrm{~L}^{-1}$ was similar to the measured efficiency during experiments with deionized water as feed, and declined to $\sim 48 \%$ before rapidly declining to almost zero due to scaling (Fig. 4a). The decline in efficiency observed in the present study is less than the theoretical efficiency decline from $50 \%$ to $40 \%$ over a similar concentration range predicted by Al-Obaidani et al. [42]; however, the membranes used in their study had lower 
thermal efficiency than the membranes used in the present study. Thermal efficiency is a function of the ratio between latent heat transfer and conduction heat transfer through the membrane; low thermal efficiency is a result of relatively high conduction heat transfer, which is independent of the properties of the water. On the other hand, the reduction in water flux due to reduced water activity at high salinity is independent of the membrane properties. For these reasons, it can be seen from Equation 5 that the effect of concentration on thermal efficiency will always be proportionally lower than the effect on water flux, although the effect will be more pronounced for membranes with low efficiency compared to those with higher efficiency. These trends are similar for the drop in thermal efficiency due to scaling/fouling unless these processes also affect the thermal conductivity of the membrane.

Performance at increased $\Delta T$ was less consistent after multiple concentration and scaling cycles, as illustrated in Fig. 3b. Initial water flux at $200 \mathrm{~g} \mathrm{~L}^{-1} \mathrm{NaCl}$ feed concentration was approximately $35 \mathrm{~L} \mathrm{~m}^{-2} \mathrm{~h}^{-1}$, which is close to $90 \%$ of the water flux when operating with deionized water as feed at similar conditions. No scaling or loss of salt rejection was observed during the first concentration cycle up to a concentration of $310 \mathrm{~g} \mathrm{~L}^{-1}$, and steady flux decline was observed as concentration increased due to the reduced driving force. Above $310 \mathrm{~g} \mathrm{~L}^{-1}$ the water flux declined sharply as $\mathrm{NaCl}$ was observed to crystallize on the membrane surface. Water flux recovered with dilution to the initial feed concentration after scaling for the first three cycles, but the onset of rapid decline occurred at a lower feed concentration with each additional concentration cycle. Finally, water flux was noticeably reduced even with dilution during the fourth concentration cycle. This additional decline in water flux coincided with a more severe decline in thermal efficiency with each additional concentration cycle (Fig. 4b). In addition, progressive decline in salt rejection occurred with each concentration cycle, with a minimum measured salt rejection of $99.4 \%, 96.9 \%, 92.4 \%$, and $91.1 \%$ for cycles 1 through 4 , occurring at the maximum concentration of each cycle. However, salt rejection recovered to $99.4 \%$ or higher when the solution was diluted back to its initial concentration of $200 \mathrm{~g} \mathrm{~L}^{-1}$. 

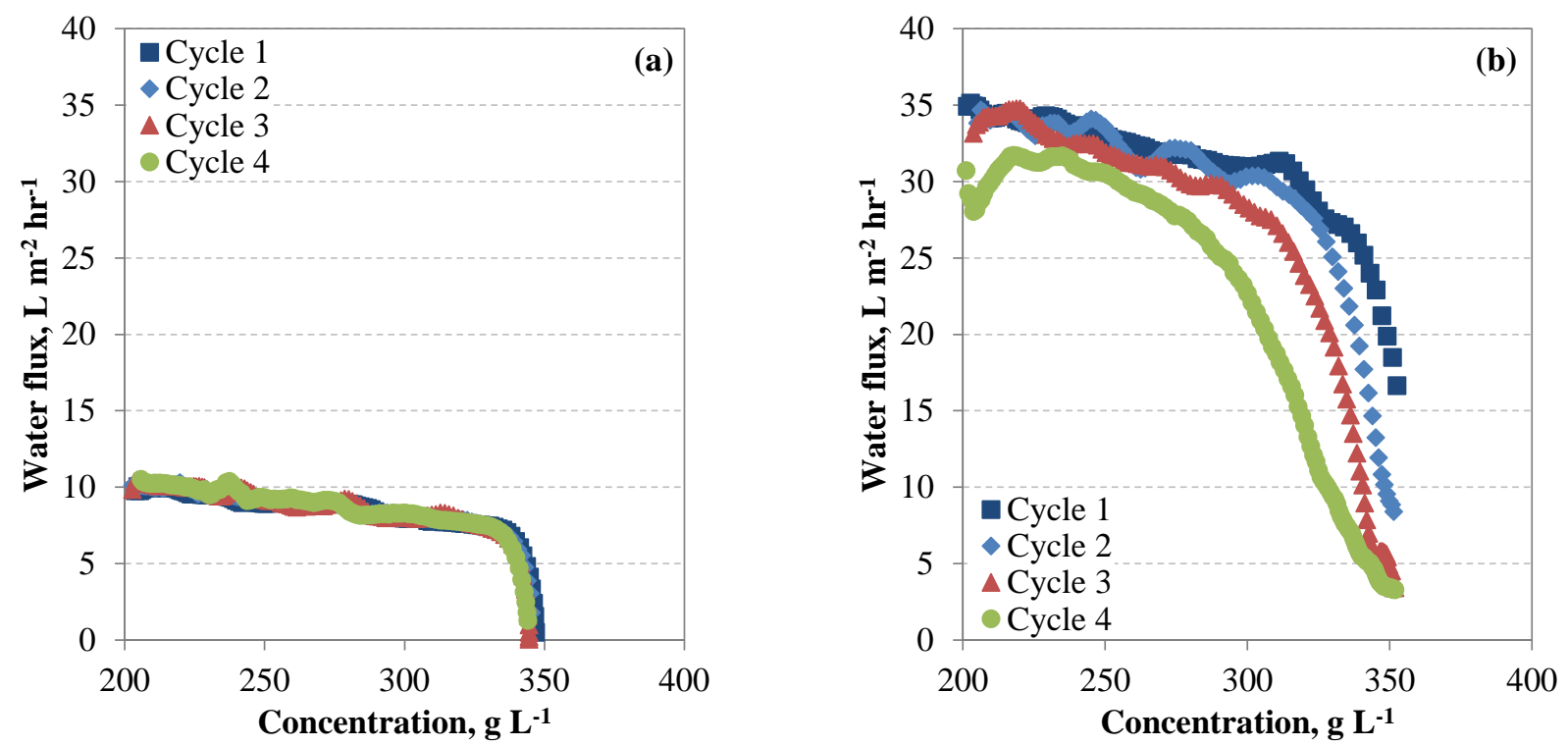

Fig. 3. Water flux using feed solution with initial concentration of $200 \mathrm{~g} \mathrm{~L}^{-1} \mathrm{NaCl}$ with constant $T_{\mathrm{d}}$ of $30{ }^{\circ} \mathrm{C}$ and constant $T_{\mathrm{f}}$ of (a) $50{ }^{\circ} \mathrm{C}$ and (b) $70{ }^{\circ} \mathrm{C}$. Both feed and distillate flow rates were 1.6 $\mathrm{L} \mathrm{min} \mathrm{m}^{-1}$ in co-current flow configuration, using Cell 1. Four concentration cycles were performed, during which the $\mathrm{NaCl}$ solution was concentrated until water flux ceased due to scaling, or the conductivity of distillate exceeded $2000 \mu \mathrm{S} \mathrm{cm}^{-1}$. After each concentration cycle the solution was diluted to original concentration.

For both conditions tested the scale layer formed during concentration was observed to dissolve upon dilution of the feed solution to its original concentration. Cross-section SEM micrographs of both membranes revealed enlarged pores in the membrane structure (Fig. 5), although the depth and extent of the damage was greater for the membrane tested with $T_{\mathrm{f}}$ of 70 ${ }^{\circ} \mathrm{C}$ (Fig. 5c) than $50{ }^{\circ} \mathrm{C}$ (Fig. 5b). Both membranes also experienced a loss of hydrophobicity, although much more so with $T_{\mathrm{f}}$ of $70{ }^{\circ} \mathrm{C}$, which resulted in a contact angle of only $38.5^{\circ}$ compared to $88.5^{\circ}$ for the membranes tested with $T_{\mathrm{f}}$ of $50{ }^{\circ} \mathrm{C}$. The membranes tested with the $T_{\mathrm{f}}$ of $70{ }^{\circ} \mathrm{C}$ also showed evidence of residual $\mathrm{NaCl}$ crystals embedded throughout the membrane, visible as bright spots in the SEM micrographs (Fig. 5c). 

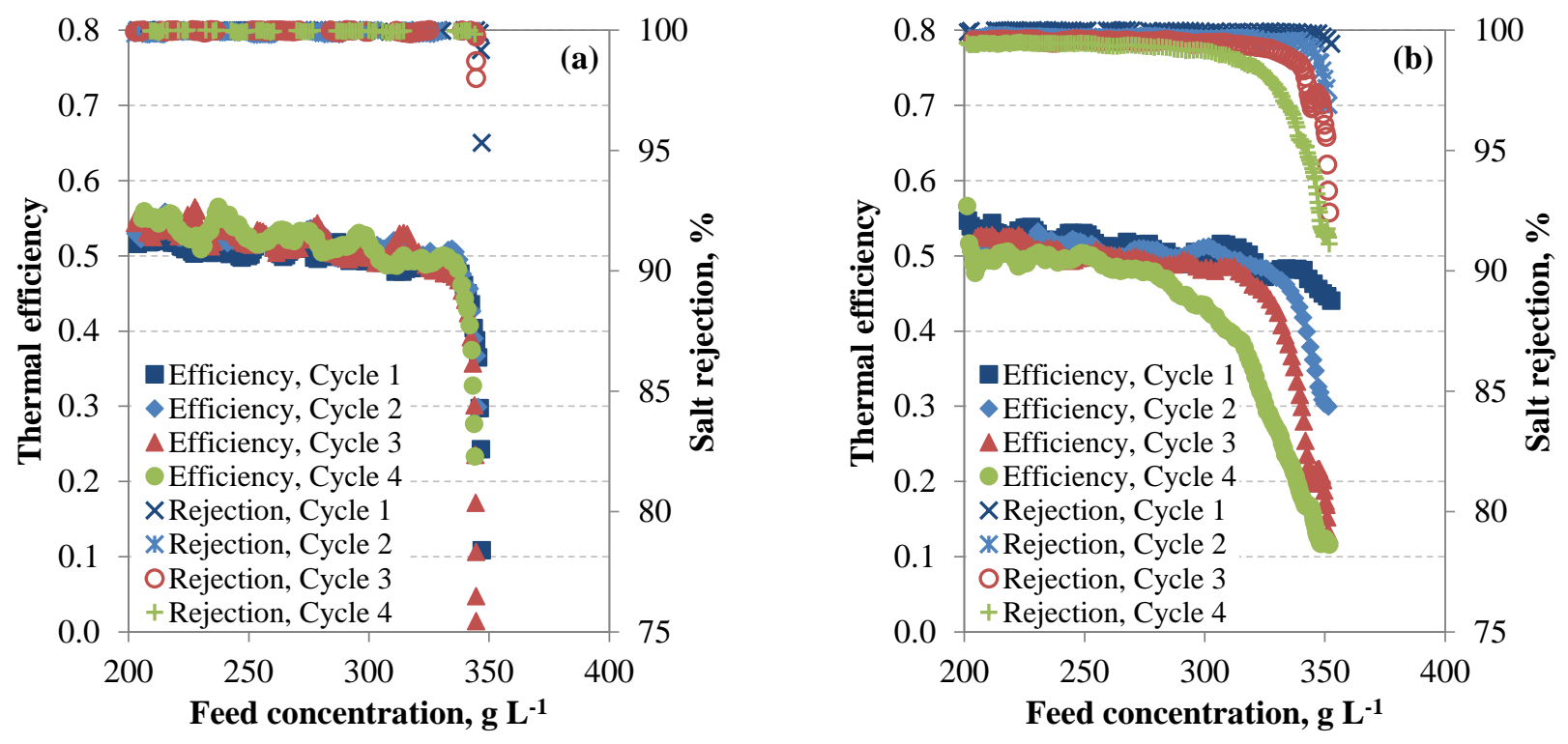

Fig. 4. Thermal efficiency and salt rejection for the experimental results presented in Fig. 3. Feed solution with initial concentration of $200 \mathrm{~g} \mathrm{~L}^{-1} \mathrm{NaCl}$, constant $T_{\mathrm{d}}$ of $30{ }^{\circ} \mathrm{C}$, and constant $T_{\mathrm{f}}$ of (a) $50{ }^{\circ} \mathrm{C}$ and (b) $70{ }^{\circ} \mathrm{C}$.

These results suggest that the liquid-vapor interface likely penetrated the membrane in both cases, leading to salt crystallization inside the membrane itself, but that the resulting changes in surface hydrophobicity or membrane pore structure does not necessarily affect performance. Complete pore flooding was only a significant factor for experiments conducted with $T_{\mathrm{f}}$ of 70 ${ }^{\circ} \mathrm{C}$. Increased $\mathrm{NaCl}$ scaling tendency and pore flooding at high $\Delta T$ has been reported in previous MD studies [30, 32], and results from the increase in concentration polarization that occurs with increased water flux. Because $\mathrm{NaCl}$ dissolves easily at concentrations below saturation, and performance was completely restored with each dilution cycle for experiments performed with $T_{\mathrm{f}}$ of $50{ }^{\circ} \mathrm{C}$, the loss of effective membrane surface area due to wetting is likely the cause of performance decline below bulk concentration of $320 \mathrm{~g} \mathrm{~L}^{-1}$ for experiments conducted with $T_{\mathrm{f}}$ of $70{ }^{\circ} \mathrm{C}$. 

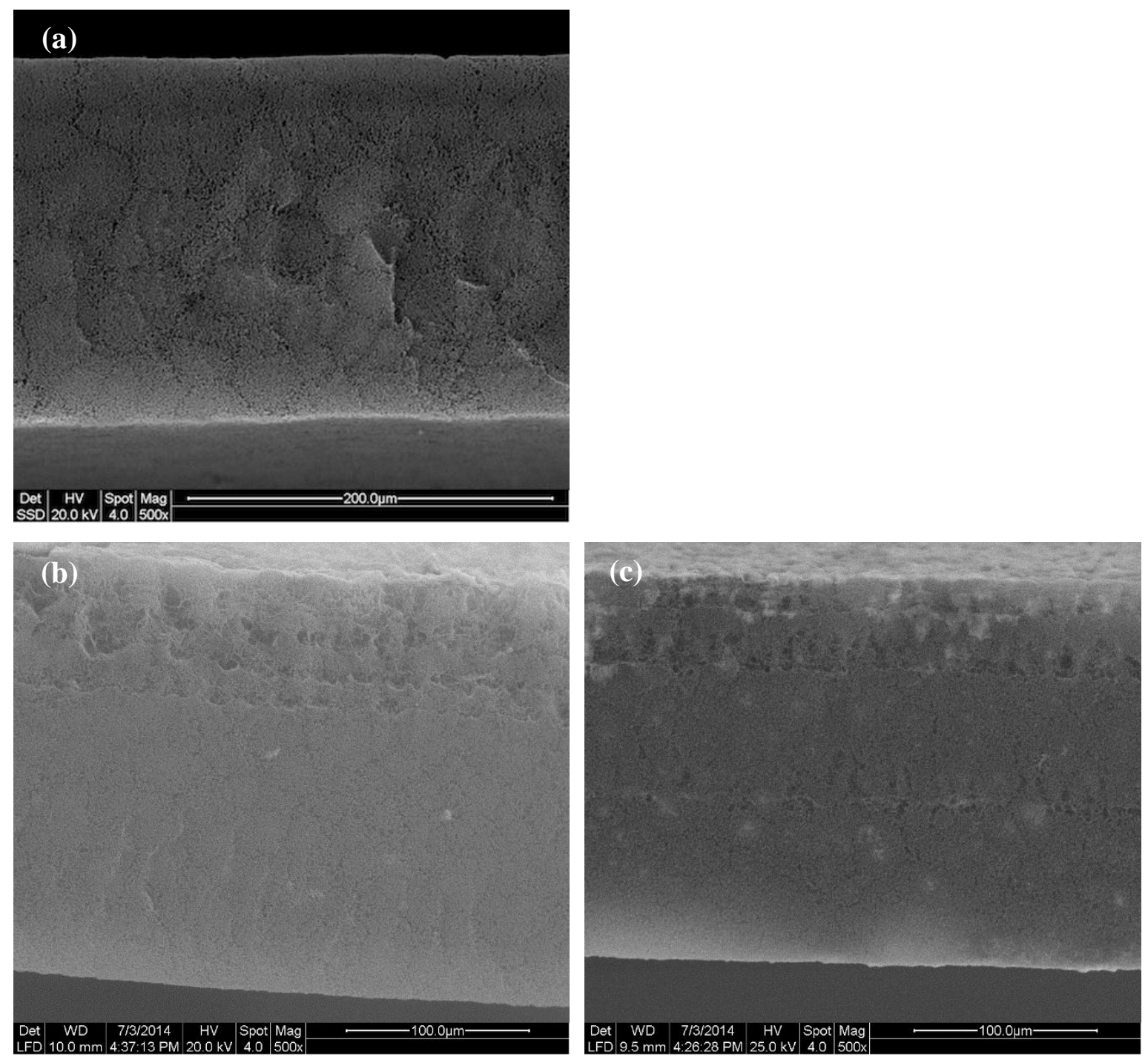

Fig. 5. Cross-section SEM micrographs of (a) virgin membrane and (b, c) membranes used with $200 \mathrm{~g} \mathrm{~L}^{-1} \mathrm{NaCl}$ solution concentrated to the point of scaling, then diluted to the original $200 \mathrm{~g} \mathrm{~L}^{-}$ ${ }^{1}$, then concentrated again for a total of four scaling cycles. Distillate temperature was constant at $30{ }^{\circ} \mathrm{C}$ and feed temperature was constant at (b) $50{ }^{\circ} \mathrm{C}$ and (b) $70^{\circ} \mathrm{C}$. Flow rates for both feed and distillate were $1.6 \mathrm{~L} \mathrm{~min}^{-1}$ in co-current configuration using Cell 1 . The side of the membrane in contact with the feed solution during experiments is towards the top of the images, where enlarged pores due to damage by $\mathrm{NaCl}$ crystallization are seen. Bright spots inside the membrane structure were revealed by EDS analysis to be $\mathrm{NaCl}$ deposits.

\subsection{Effects of scaling with North Arm GSL water}

\subsubsection{Single batch concentration}

The performance and limitations of the MD process applied to the GSL brine was initially determined by concentrating the brine at $T_{\mathrm{f}}$ of $50{ }^{\circ} \mathrm{C}$ and $T_{\mathrm{f}}$ of $30{ }^{\circ} \mathrm{C}$. Water flux and concentration factor of the feed as a function of time are shown in Fig. 6a. Initial water flux was 
$8.3 \mathrm{~L} \mathrm{~m}^{-2} \mathrm{~h}^{-1}$, or $55 \%$ of the water flux when operating with deionized water as feed at similar conditions. Water flux declined by an additional 3\% as the concentration factor increased to approximately 1.08 , which is slightly higher than the $\mathrm{NaCl}$ saturation concentration factor of 1.07. As concentration increased the water flux sharply declined over a period of almost 3 hours. This rapid decline and ultimate termination of water flux coincided with a visible scale layer that formed on the membrane surface once the concentration factor exceeded 1.11. No increase in conductivity in the distillate was observed over the duration of the experiment, indicating complete rejection of dissolved salts.
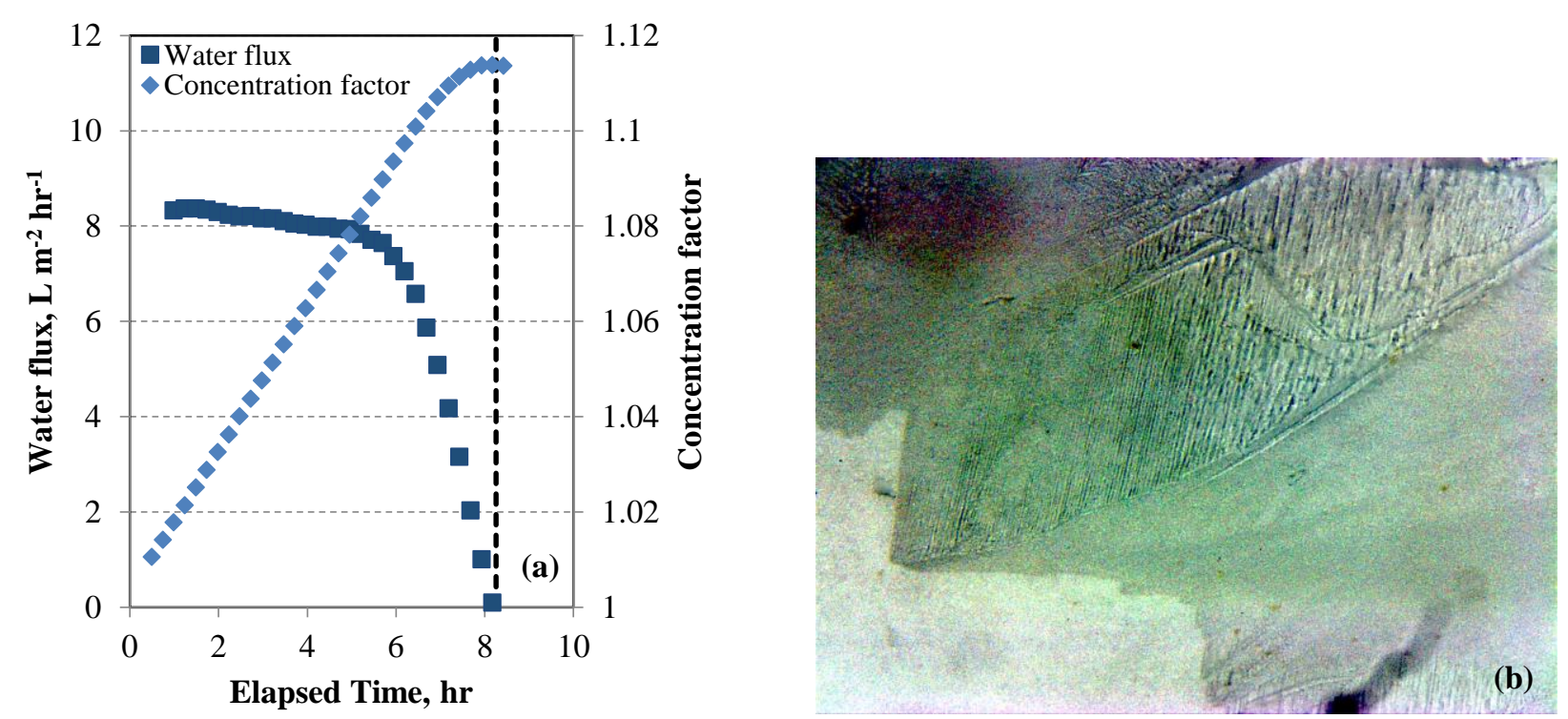

Fig. 6. (a) Water flux and concentration factor as a function of time for the experiment conducted with GSL brine feed at a constant temperature of $50{ }^{\circ} \mathrm{C}$ and with distillate temperature of $30{ }^{\circ} \mathrm{C}$. Flow rates for both feed and distillate were $1.6 \mathrm{~L} \mathrm{~min}^{-1}$ in co-current configuration using Cell 2. (b) Optical micrograph showing scale layer on membrane surface taken at the point of maximum concentration. Vertical dashed line on plot (a) indicates the time during experiment that image (b) was recorded.

The scale layer observed using optical microscopy appeared as a continuous sheet with cubic morphology characteristic of $\mathrm{NaCl}$, and no additional nucleation sites on the membrane surface were visible within the field of view (Fig. 6b). The morphology, timing of occurrence, and similar effect on performance as occurred during the pure $\mathrm{NaCl}$ experiments suggest that the observed scale layer was composed primarily of $\mathrm{NaCl}$, which crystallizes readily despite the presence of impurities [51]. Also, because $\mathrm{NaCl}$ solubility increases with temperature [52], the scaling tendency is likely to be higher at the membrane surface than the bulk solution. 


\subsubsection{Effect of multiple scaling cycles with North Arm GSL brine}

To investigate the effects of concentration and scaling on long term performance, repeated concentration and dilution cycles were performed using the GSL brine. Feed temperature for these experiments were constant at $50{ }^{\circ} \mathrm{C}$ or $70{ }^{\circ} \mathrm{C}$, and the distillate temperature was constant 30 ${ }^{\circ} \mathrm{C}$. Water flux results were quite different between the low and high $\Delta T$ experiments (Fig. 7). Initial water flux with $T_{\mathrm{f}}$ of $50{ }^{\circ} \mathrm{C}$ was $6.7 \mathrm{~L} \mathrm{~m}^{-2} \mathrm{~h}^{-1}$, or $55 \%$ of the water flux when operating with deionized water as feed at similar conditions. A gradual decline in water flux with concentration was observed that became progressively more severe as the concentration factor approached 1.1, and with each additional concentration cycle (Fig. 7a), although the water flux was restored to its initial rate each time the brine was diluted to its initial concentration. Salt rejection was very high except at the highest concentrations reached, and even at a concentration factor exceeding $\mathrm{NaCl}$ saturation it was greater than 99.7\%. Thermal efficiency also progressively declined with concentration and with additional concentration cycles, following a similar trend as the water flux (Fig. 8a).

Initial water flux with $T_{\mathrm{f}}$ of $70{ }^{\circ} \mathrm{C}$ was $25.3 \mathrm{~L} \mathrm{~m}^{-2} \mathrm{~h}^{-1}$, or $65 \%$ of the water flux when operating with deionized water as feed at similar conditions. In contrast to the experiments performed with $T_{\mathrm{f}}$ of $50{ }^{\circ} \mathrm{C}$, the water flux declined rapidly with concentration, and was not fully restored when the brine was returned to its initial concentration (Fig. 7b). Salt rejection declined below $99 \%$ at the highest concentration of the first concentration cycle. Although salt rejection recovered when the brine was diluted to its initial concentration, it declined further with additional concentration cycles, and by the final concentration cycle declined below $98 \%$. Thermal efficiency was almost constant for the first concentration cycle up to a concentration factor of approximately 1.09, but sharply declined as the concentration further increased (Fig. 8b). As with water flux, thermal efficiency was not fully recovered when the brine was diluted to its initial concentration, and further declined with each additional concentration cycle. 

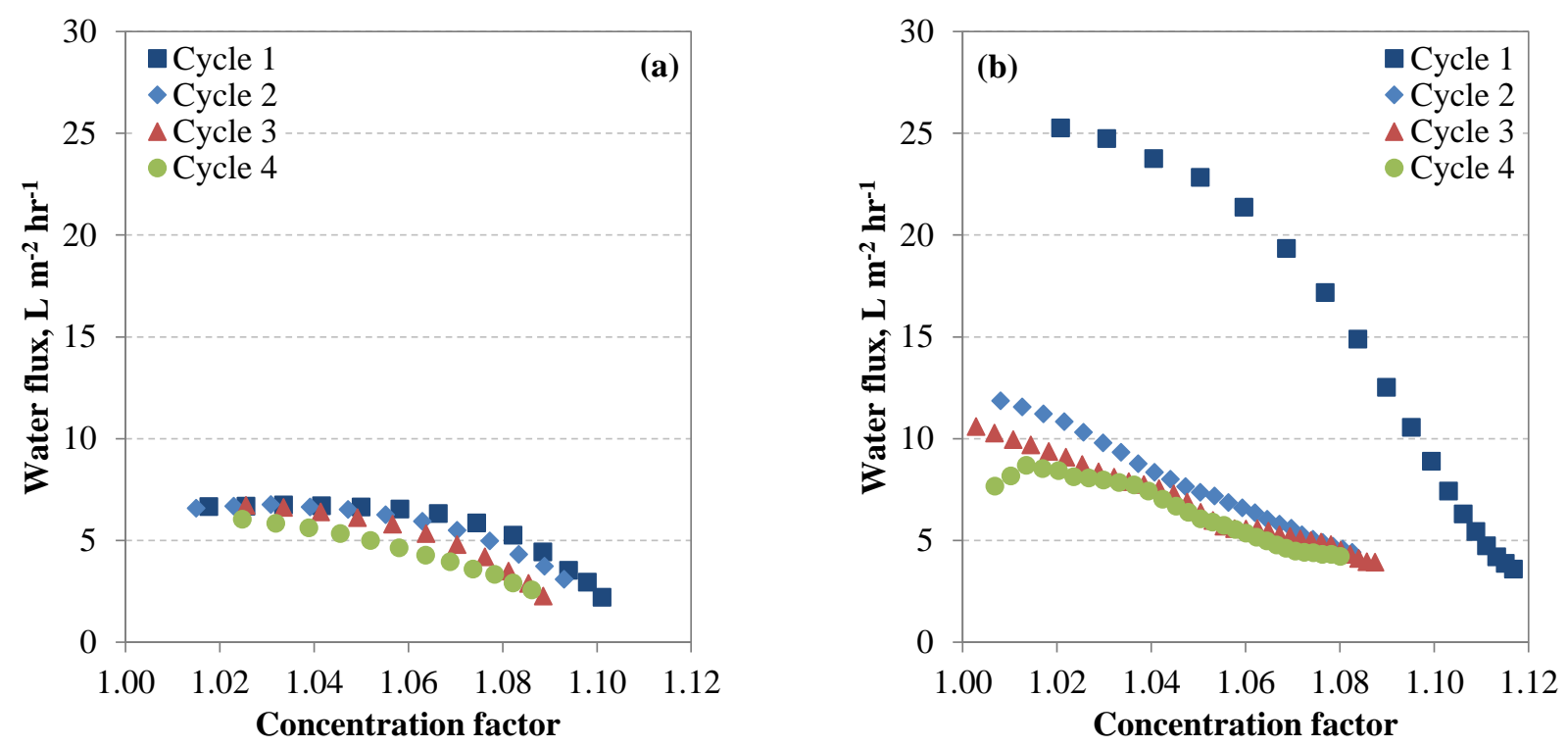

Fig. 7. Water flux as a function of concentration factor for experiments with GSL brine as feed solution, constant $T_{\mathrm{d}}$ of $30^{\circ} \mathrm{C}$, and constant $T_{\mathrm{f}}$ of (a) $50^{\circ} \mathrm{C}$ and (b) $70{ }^{\circ} \mathrm{C}$. Both feed and distillate flow rates were $1.6 \mathrm{~L} \mathrm{~min}^{-1}$ in co-current flow configuration, using Cell 1. Four concentration cycles were performed, during which the GSL water was concentrated until flux declined below $50 \%$ of its initial value due to scaling, or the conductivity of distillate exceeded $2000 \mu \mathrm{S} \mathrm{cm}^{-1}$. After each concentration cycle the solution was diluted to original concentration.
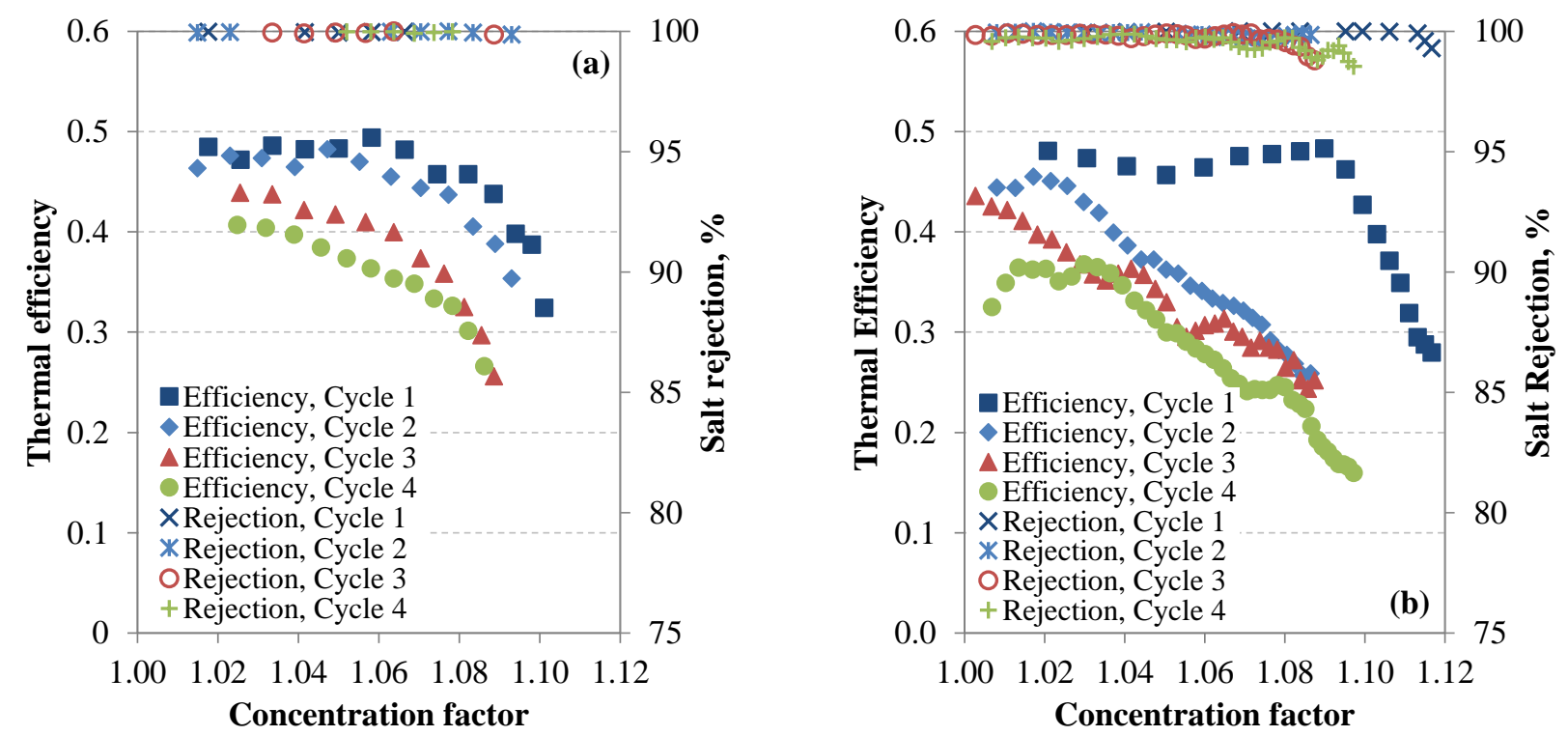

Fig. 8. Thermal efficiency and salt rejection for experimental data presented in Fig. 7. GSL brine was the feed solution with constant $T_{\mathrm{d}}$ of $30^{\circ} \mathrm{C}$ and constant $T_{\mathrm{f}}$ of (a) $50{ }^{\circ} \mathrm{C}$ and (b) $70{ }^{\circ} \mathrm{C}$.

The membranes were analyzed using SEM and EDS to investigate scaling morphology and composition. Several distinct crystalline structures formed on the surface of the membrane used 
for the experiments performed with $T_{\mathrm{f}}$ of $50{ }^{\circ} \mathrm{C}$ and are shown in Fig. 9. EDS analysis found predominantly $\mathrm{NaCl}$ layers (Fig. 9a-1) that also appeared to serve as nucleation sites for crystals containing magnesium and chloride, but also potassium and oxygen in smaller quantities (Fig. 9a-2). Smaller crystals on the membrane itself were found to contain predominantly magnesium, sulfur, and oxygen, but also chloride (Fig. 9a-3). Cross-section images of the same membrane showed indications that a crystalline scale layer had penetrated the membrane structure (Fig. 9b). The extent of penetration varied and was not complete, and had advanced to approximately a quarter of the total thickness of the membrane in some areas. This area of the membrane also showed signs of damage to the membrane structure, as abnormally large pores were noted throughout the area that had experienced scale layer penetration. Isolated crystals where also observed scattered randomly throughout the remainder of the membrane structure.

The surfaces of the membranes used for the experiments performed with $T_{\mathrm{f}}$ of $70{ }^{\circ} \mathrm{C}$ were absent of large, distinct crystalline structures. EDS analysis revealed sodium and chloride present on the membrane surface, but the cubic structure typical of $\mathrm{NaCl}$ was not observed. The primary large surface structures appeared as an amorphous layer containing predominantly magnesium, chloride, and oxygen (Fig. 10a), mostly in the areas of the membrane that had been close to the spacer filaments. Cross-section images indicate that scaling had penetrated into the membrane structure and was more homogeneous than the scaling that occurred during experiments with $T_{\mathrm{f}}$ of $50{ }^{\circ} \mathrm{C}$ (Fig. 10b). The internal damage to the membrane structure was more severe than the membranes tested with $T_{\mathrm{f}}$ of $50{ }^{\circ} \mathrm{C}$, and very large pores were found throughout the membrane approximately a quarter to a third of the distance from the feed surface to the distillate surface. These enlarged pores also contained crystals that EDS identified to be composed of $\mathrm{NaCl}$, indicating that liquid water likely penetrated the membrane structure to some extent. Both membranes experienced similar decline in hydrophobicity following the experiments, and contact angles of $52.2^{\circ}$ and $58.8^{\circ}$ were measured for the membranes used for experiments performed with $T_{\mathrm{f}}$ of $50{ }^{\circ} \mathrm{C}$ and $70{ }^{\circ} \mathrm{C}$, respectively. 

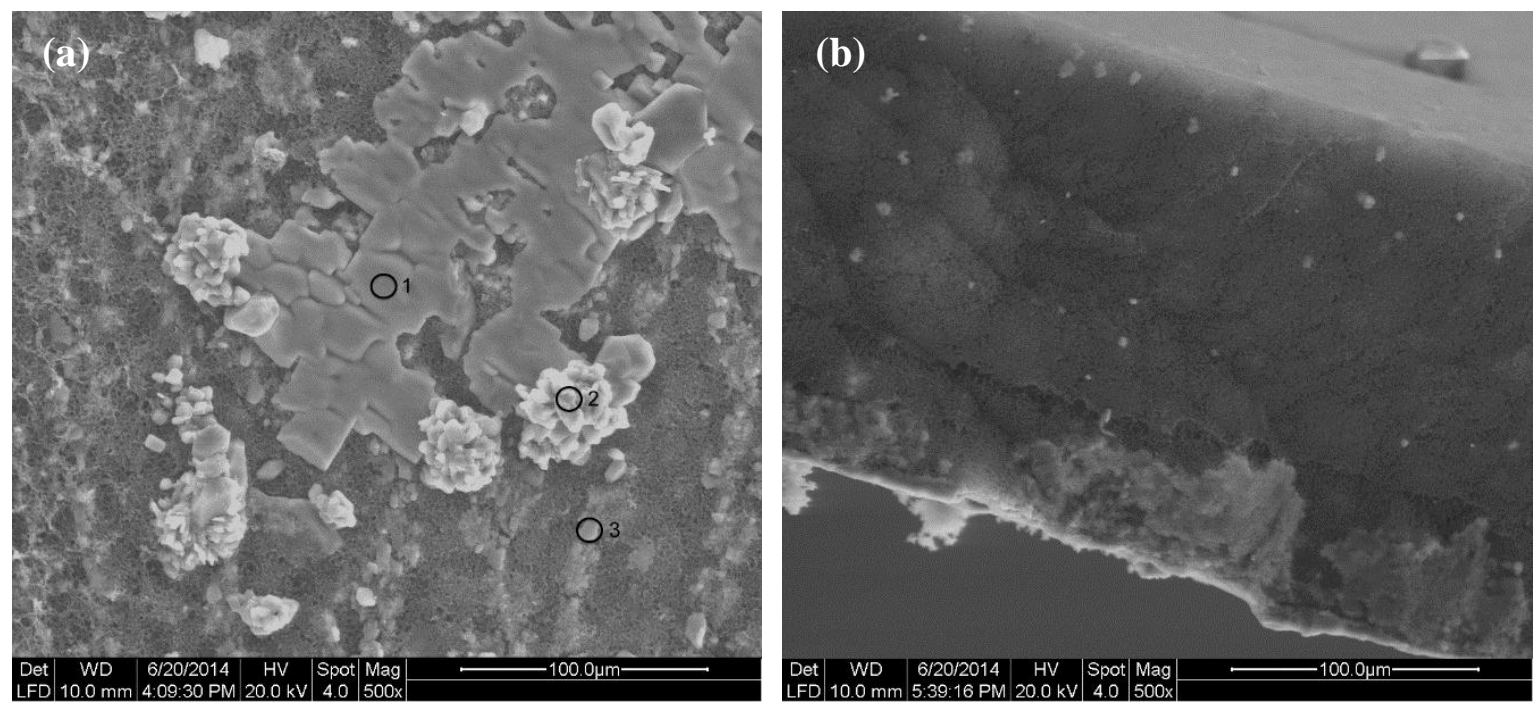

Fig. 9. (a) Surface and (b) cross-section SEM micrographs of the membrane used with GSL brine as feed, constant $T_{\mathrm{f}}$ of $50{ }^{\circ} \mathrm{C}$, constant $T_{\mathrm{d}}$ of $30^{\circ} \mathrm{C}$, with feed and distillate flow rate of 1.6 $\mathrm{L} \mathrm{min}^{-1}$ co-current flow using Cell 1 . Four concentration cycles were performed. Surface layers included predominantly $\mathrm{NaCl}$ (1), (2) crystals containing magnesium, chloride, potassium, and oxygen, and (3) scale containing magnesium, sulfur, oxygen, and chloride. Membrane feed side is towards bottom of image (b), where enlarged pores similar to those seen in membranes scaled with pure $\mathrm{NaCl}$ (Fig. 5) are visible.
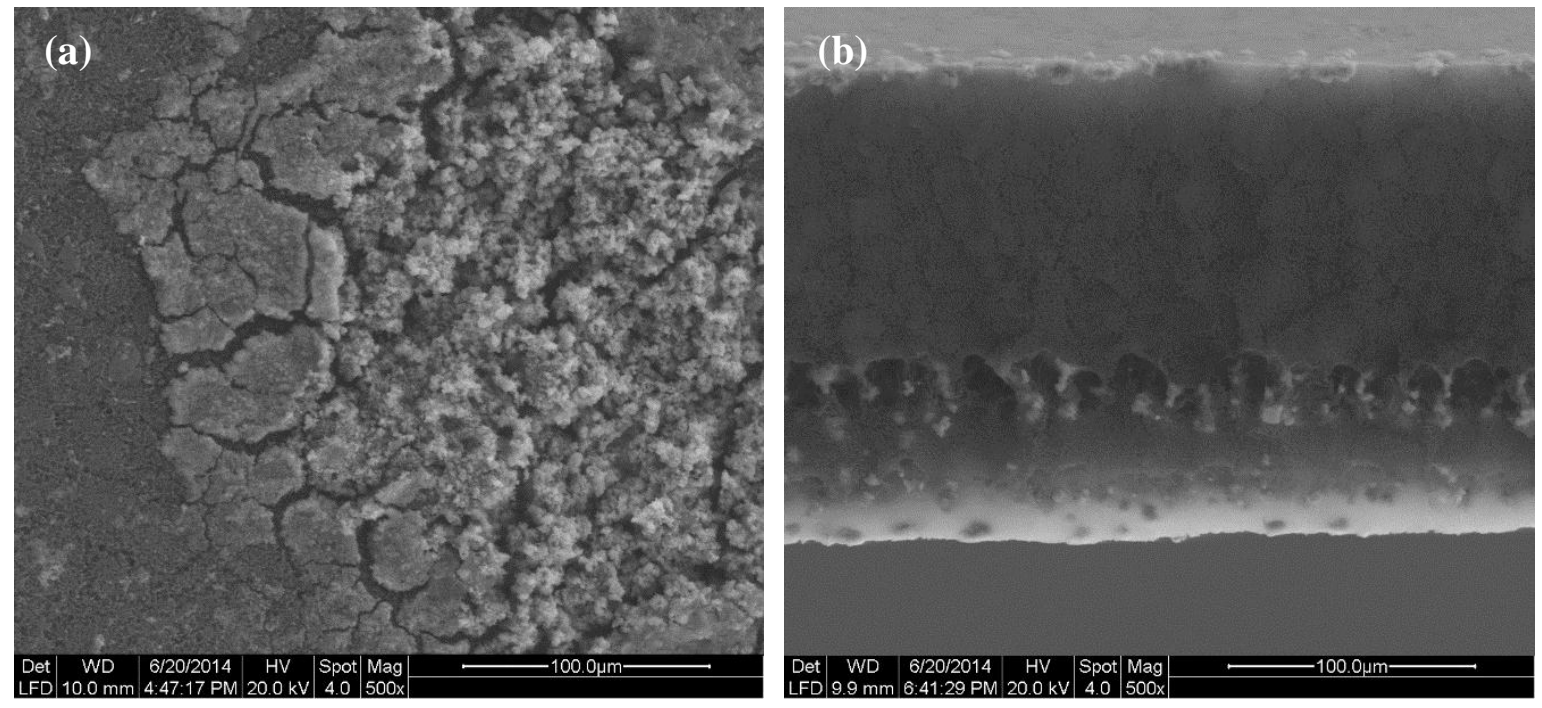

Fig. 10. (a) Surface and (b) cross-section SEM micrographs of the membrane used with GSL brine as feed, constant $T_{\mathrm{f}}$ of $70{ }^{\circ} \mathrm{C}$, constant $T_{\mathrm{d}}$ of $30^{\circ} \mathrm{C}$, with feed and distillate flow rate of 1.6 $\mathrm{L} \mathrm{min}^{-1}$ co-current flow using Cell 1 . Four concentration cycles were performed. Surface layers were predominantly composed of amorphous structures containing sodium, magnesium, chloride, and oxygen. Membrane feed side is towards bottom of image (b). Damage to the membrane structure was more severe, with pores enlarged to a greater degree than those seen in membranes scaled with pure $\mathrm{NaCl}$ (Fig. 5). 


\subsubsection{Comparison of scaling and fouling between GSL water and pure NaCl solution}

Compared to the effects of scaling with pure $\mathrm{NaCl}$, there appear to be several factors that contribute to a decline in water flux and thermal efficiency for the MD process when used to concentrate the GSL water. These include reversible effects that recover when the concentration is decreased with all other conditions being the same, and irreversible effects that do not recover when the concentration decreases. Moreover, the irreversible effects are much more significant at higher $\Delta T$ operation. $\mathrm{NaCl}$ crystallization is likely the predominant cause of the reversible decline at high concentrations; the visible scale layer covering the membrane surface disappeared with reduced concentration as the $\mathrm{NaCl}$ crystals dissolved. Of all the conditions tested, only the pure $\mathrm{NaCl}$ experiments with a $T_{\mathrm{f}}$ of $50{ }^{\circ} \mathrm{C}$ did not exhibit significant irreversible decline. Although irreversible decline was observed in the $\mathrm{NaCl}$ experiments performed with $T_{\mathrm{f}}$ of $70{ }^{\circ} \mathrm{C}$, this is likely related to pore wetting and the loss of effective surface area due to the rapid dissolution of the $\mathrm{NaCl}$ scale layer when the solution was diluted below saturation concentration. Pore wetting is not likely to be the primary cause of irreversible decline in the North Arm GSL experiments, as severe decline in performance was observed in both sets of experiments despite negligible decline in salt rejection.

Unlike the pure $\mathrm{NaCl}$ experiments, which saw steady performance decline in the first concentration cycle up until $\mathrm{NaCl}$ saturation due to increased concentration, performance decline in the North Arm GSL experiments experienced a progressive decline in flux almost immediately, and was especially rapid in the experiments performed with $T_{\mathrm{f}}$ of $70{ }^{\circ} \mathrm{C}$. SEM and EDS analysis of membranes from both sets of experiments showed evidence of magnesium, chloride, and oxygen on the surface (Fig. 9 and Fig. 10) despite the fact that no magnesium salts exceeded saturation at the bulk concentrations experienced during the experiments. However, generally speaking the GSL brine is very high in magnesium and is an economically important source of $\mathrm{MgCl}_{2}$ [53]. Solubility of $\mathrm{MgCl}_{2}$ increases with temperature, and high $\mathrm{NaCl}$ concentrations inhibit the diffusion of $\mathrm{Mg}^{2+}$ [54]. Therefore, it is plausible that the increase in temperature and concentration polarization at higher $\Delta T$ may have created conditions favorable to $\mathrm{MgCl}_{2}$ crystallization at the membrane surface despite below-saturation concentration in the bulk solution.

Another possible explanation for the irreversible effects may be fouling by colloid-sized particles present in the water. Whereas water flux for pure $\mathrm{NaCl}$ experiments was mostly 
independent of total water recovered at both low and high $\Delta T$, a convergence in performance was observed in the North Arm GSL experiments for the different operating temperatures. By the $4^{\text {th }}$ concentration cycle and approximately $1 \mathrm{~L}$ of total water recovery, water flux was similar for both $T_{\mathrm{f}}=50{ }^{\circ} \mathrm{C}$ and $T_{\mathrm{f}}=70{ }^{\circ} \mathrm{C}$ experiments even at reduced concentration, despite the much greater driving force at higher $\Delta T$ (Fig. 11). Similar behavior has also been observed in pressuredriven membrane processes where fouling is primarily a result of the deposition of colloid-size particles [55]. This flux convergence phenomenon is largely due to the interplay between the normal hydraulic drag force that results from the water flux, the barrier force that results from the membrane-colloid interaction, and the shear hydraulic force that results from the bulk flow rate of the feed. The GSL water used in the present study was high in total organic carbon (TOC) and magnesium (Table 1). Divalent cations are known to form complexes with carboxyl groups in natural organic matter $(\mathrm{NOM})$ and enhance fouling rates in membrane filtration processes [56, 57]. It is possible that such complexes may have formed in the GSL water during concentration and deposited onto the membrane surface into a fouling layer. The presence of magnesium and oxygen on the membranes used in experiments performed with $T_{\mathrm{f}}$ of $70{ }^{\circ} \mathrm{C}$ as well as the amorphous nature of the surface structures observed in the SEM analysis (Fig. 10) provide support for the explanation that this fouling may be a result of NOM- $\mathrm{Mg}^{2+}$ complexes.

EDS analysis did not indicate presence of calcium in the scaling or fouling layer of any of the membranes tested, despite the fact that calcium is also known to form complexes with NOM, and the OLI simulation predicted high scaling tendency for both $\mathrm{CaCO}_{3}$ and $\mathrm{CaSO}_{4}$. However, the concentration of magnesium in the GSL brine was an order of magnitude greater than the concentration of calcium. Additionally, $\mathrm{CaSO}_{4}$ crystallization has a relatively long induction time and is inhibited by the presence of $\mathrm{NaCl}$ [58]. Dissolved organic matter, specifically humid acid, has also been shown to inhibit $\mathrm{CaCO}_{3}$ scaling in the DCMD process [35]. 

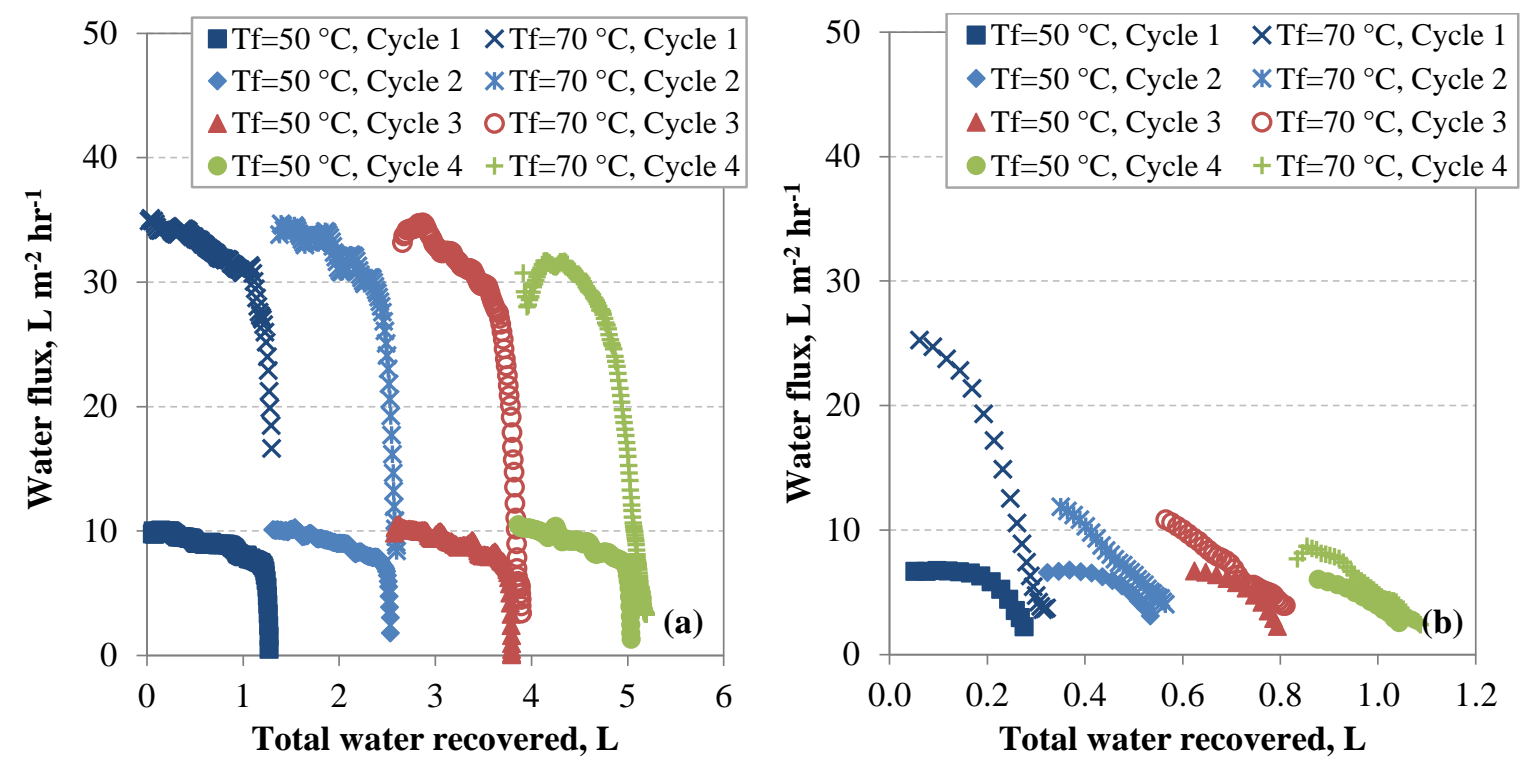

Fig. 11. Comparison of water flux for $T_{\mathrm{f}}$ of $50{ }^{\circ} \mathrm{C}$ and $T_{\mathrm{f}}$ of $70{ }^{\circ} \mathrm{C}$ over four concentration and dilution cycles for (a) $200 \mathrm{~g} \mathrm{~L}^{-1} \mathrm{NaCl}$ solution and (b) North Arm GSL brine using Cell 1, plotted as a function of total water recovered. Distillate temperature was constant at $30{ }^{\circ} \mathrm{C}$ and flow rate for both feed and distillate was $1.6 \mathrm{~L} \mathrm{~min}^{-1}$ in co-current configuration.

\subsubsection{Repeated concentration at reduced water recovery}

To investigate long-term scaling and fouling behavior while limiting potential damage to the membrane caused by $\mathrm{NaCl}$ scaling, additional concentration and dilution experiments were performed with the total water recovery limited to $8 \%$. These experiments were performed using $T_{\mathrm{f}}$ of $50{ }^{\circ} \mathrm{C}$ and $T_{\mathrm{d}}$ of $30{ }^{\circ} \mathrm{C}$. The initial water flux was close to $9 \mathrm{~L} \mathrm{~m}^{-2} \mathrm{~h}^{-1}$ and declined to approximately $8.5 \mathrm{~L} \mathrm{~m}^{-2} \mathrm{~h}^{-1}$ with increased concentration (Fig. 12). Similar to the experiments at higher water recovery, water flux declined with each additional concentration cycle, even in the absence of severe flux decline characteristic of $\mathrm{NaCl}$ scaling. Also, a decline in salt rejection was observed beginning with the $5^{\text {th }}$ concentration cycle after 25 hours of operation, ultimately falling below $98.5 \%$ towards the end of the $7^{\text {th }}$ concentration cycle.

SEM analysis of the membranes used in these experiments indicated a fouling layer similar to that observed in the concentration experiments with $T_{\mathrm{f}}$ of $70{ }^{\circ} \mathrm{C}$; however, it was much more extensive and covered most of the membrane surface (Fig. 13a). The lower temperature and concentration polarization, lower overall concentration factor, and longer overall time of these experiments providing further support for the hypothesis that the fouling layer was a result of deposition of NOM- $\mathrm{Mg}^{2+}$ over time rather than crystallization of magnesium salts. Cross-section images indicated that this layer formed only on the membrane surface and did not penetrate into 
the membrane structure itself, and unlike the experiments performed at higher water recovery did not display enlarged pores in the membrane structure (Fig. 13b). However, loss of hydrophobicity was more severe than the experiments with higher recovery but shorter duration, and the membrane used in this run of experiments was found to have a contact angle of only $28.2^{\circ}$, which may explain the increased wetting tendency and decline in salt rejection.

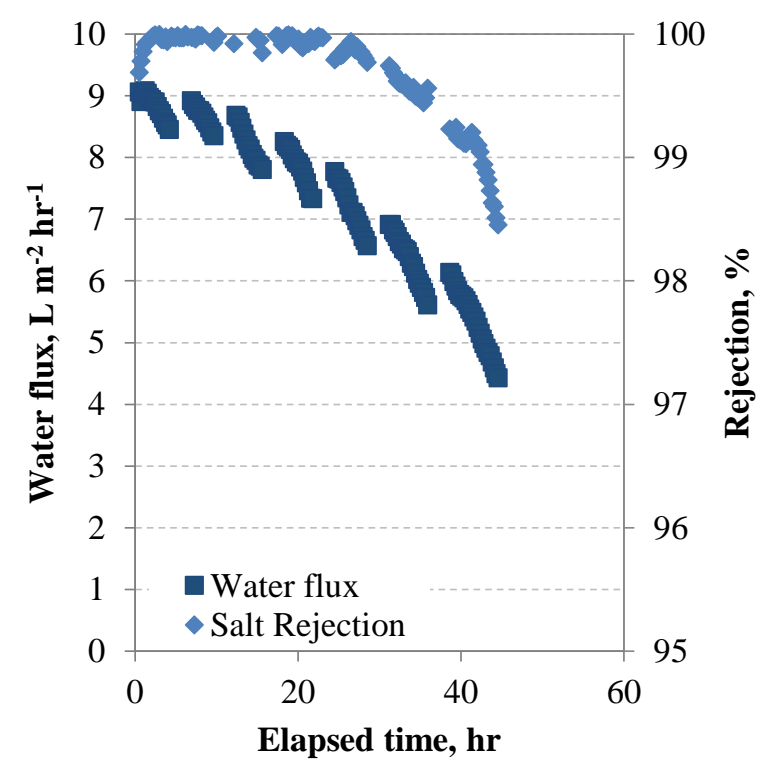

Fig. 12. Water flux and salt rejection as a function of time for experiments using GSL brine as feed, constant $T_{\mathrm{f}}$ of $50{ }^{\circ} \mathrm{C}$, and constant $T_{\mathrm{d}}$ of $30{ }^{\circ} \mathrm{C}$ over seven concentration and dilution cycles using Cell 2. For each concentration cycle the brine was concentrated until $8 \%$ recovery before dilution. Both feed and distillate flow rates were constant $1.6 \mathrm{~L} \mathrm{~min}^{-1}$ in co-current configuration.
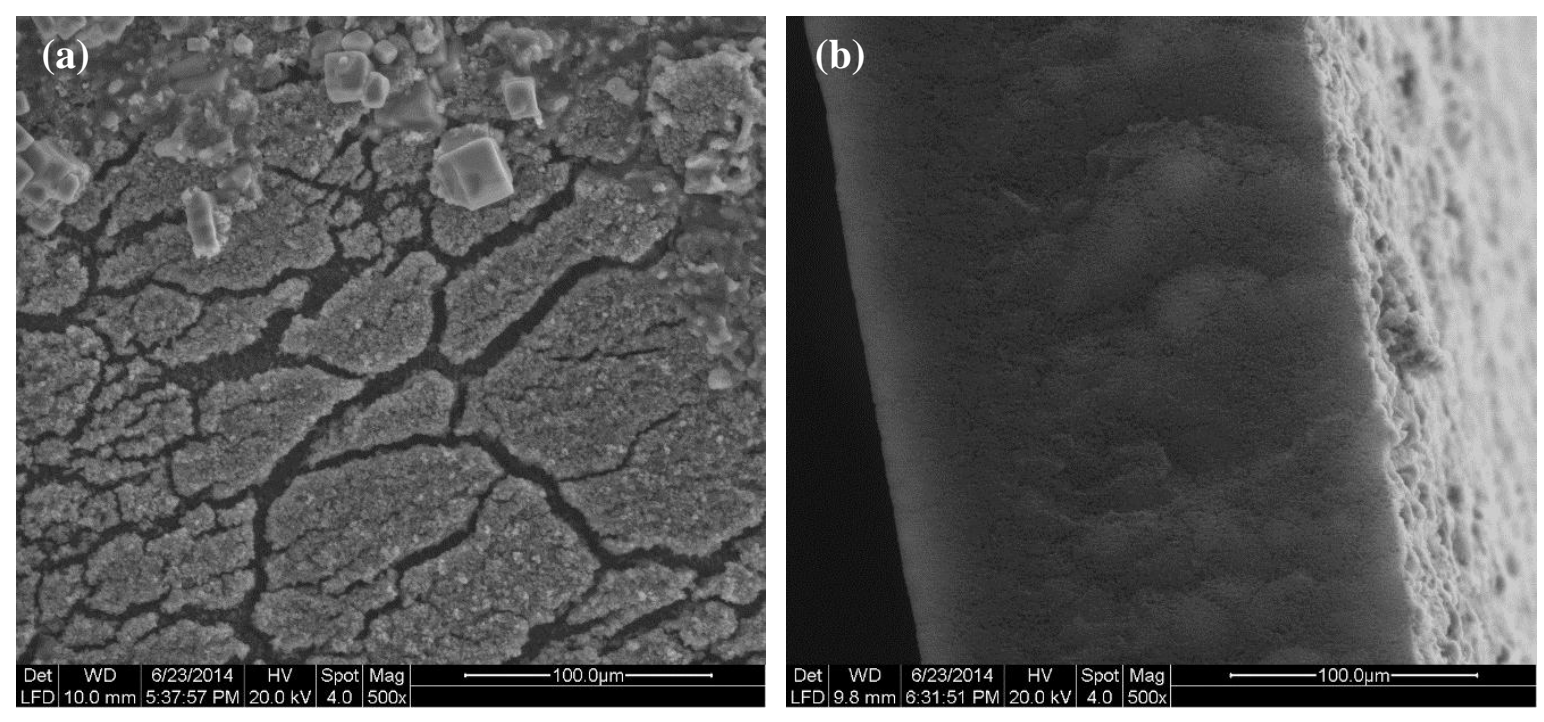
Fig. 13. (a) Surface and (b) cross-section SEM micrographs of membrane used for 7 concentration cycles using GSL brine as feed, constant $T_{\mathrm{f}}$ of $50{ }^{\circ} \mathrm{C}$, constant $T_{\mathrm{d}}$ of $30{ }^{\circ} \mathrm{C}$ over seven concentration and dilution cycles using Cell 2. For each concentration cycle the brine was concentrated until $8 \%$ recovery before dilution. Both feed and distillate flow rates were constant $1.6 \mathrm{~L} \mathrm{~min}^{-1}$ in co-current configuration. Feed side of the membrane is towards the right in image (b).

\subsubsection{Scale mitigation}

Limiting the extent of concentration to prevent scaling by $\mathrm{NaCl}$ was successful at preventing damage to the membrane itself; however, fouling still occurred and resulted in loss of performance and salt rejection. Temporary operation with $T_{\mathrm{f}}$ of $20^{\circ} \mathrm{C}$ and $T_{\mathrm{d}}$ of $30{ }^{\circ} \mathrm{C}$ between each concentration cycle to reverse the direction of water flux was tested for its effectiveness in preventing scaling and fouling buildup, and to maintain long-term performance and salt rejection.

Repeating the concentration and dilution experiments with 5 minutes of reverse temperature operation between each concentration cycle reduced the extent of performance decline compared to previous experiments performed without temperature reversal (Fig. 14a), but gradual decline in water flux and salt rejection were both observed. The technique was substantially more effective when reverse temperature operation continued until reverse water flux reached steady state, which generally took 20-40 minutes (Fig. 14b). SEM micrographs revealed little evidence of scaling or fouling on the membrane surfaces (Fig. 15a), or in the membrane pores themselves (Fig. 15b). Contact angle was found to be $89.6^{\circ}$, which is similar to the contact angle of the membrane used in the pure $\mathrm{NaCl}$ experiments with feed temperature at $50{ }^{\circ} \mathrm{C}$.

The efficacy of reversing the temperature gradient to mitigate the performance loss due to scaling/fouling suggests that organic fouling was more substantial than scaling by magnesium salts. Operation in this mode reverses the temperature and concentration polarization, creating conditions that should easily dissolve salts of the composition identified by EDS analysis such as $\mathrm{MgCl}_{2}, \mathrm{KCl}, \mathrm{K}_{2} \mathrm{SO}_{4}$. In contrast, organic fouling (e.g. NOM, humic acid) generally requires rinsing with DI water accompanied by acid/base cleaning to fully recover performance in the MD process $[59,60]$. 

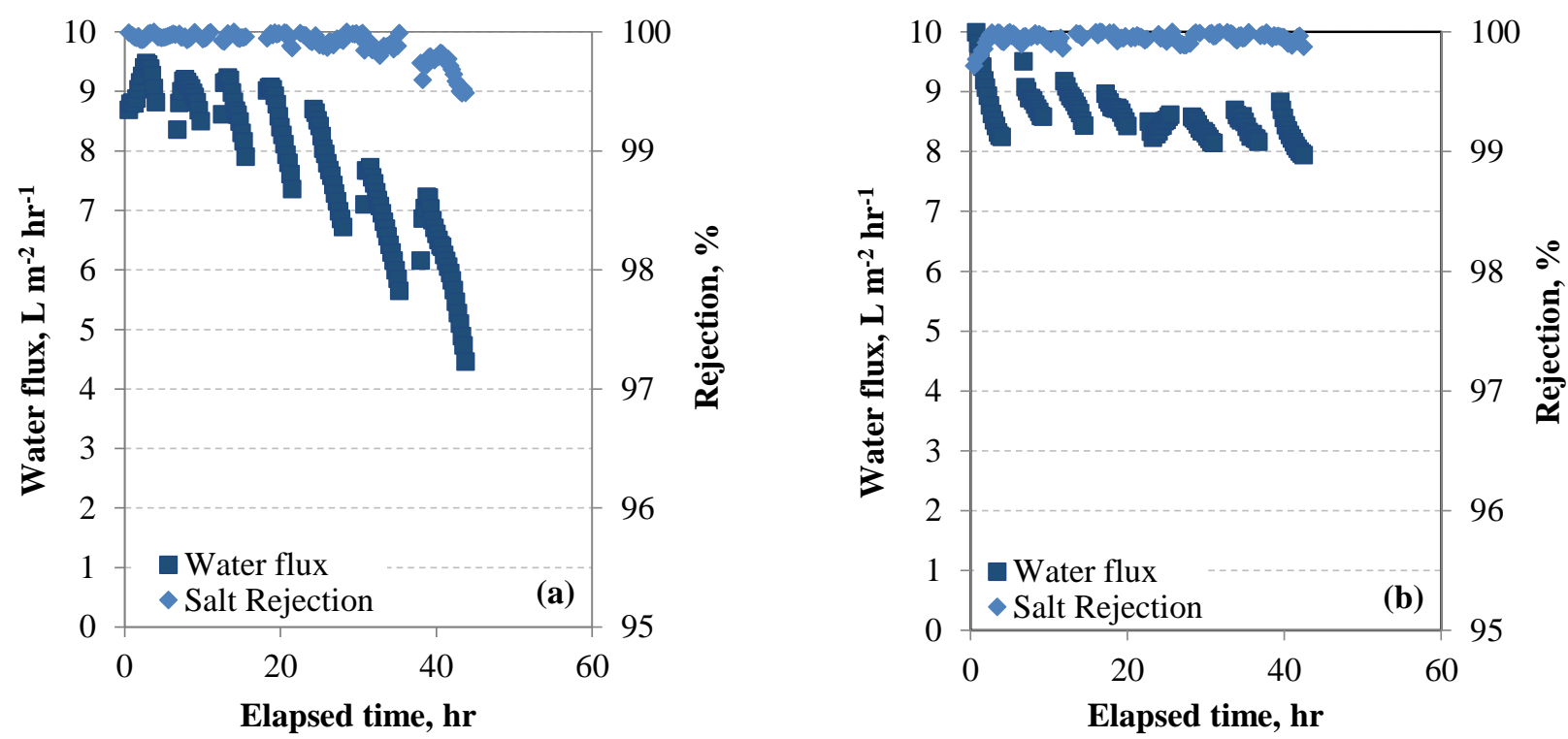

Fig. 14. Water flux and salt rejection as a function of time for multiple concentration and dilution cycles with temperature reversal using GSL brine as feed, constant $T_{\mathrm{f}}$ of $50{ }^{\circ} \mathrm{C}$, and constant $T_{\mathrm{d}}$ of $30^{\circ} \mathrm{C}$ using Cell 2 . For each concentration cycle the brine was concentrated until $8 \%$ recovery before dilution, followed by temporary operation with GSL brine at constant $T_{\mathrm{f}}$ of $20{ }^{\circ} \mathrm{C}$ and constant $T_{\mathrm{d}}$ of $30{ }^{\circ} \mathrm{C}$ for (a) 5 minutes or (b) until stable reverse flux was observed before beginning the next concentration cycle. Both feed and distillate flow rates were constant $1.6 \mathrm{~L}$ $\min ^{-1}$ in co-current configuration.
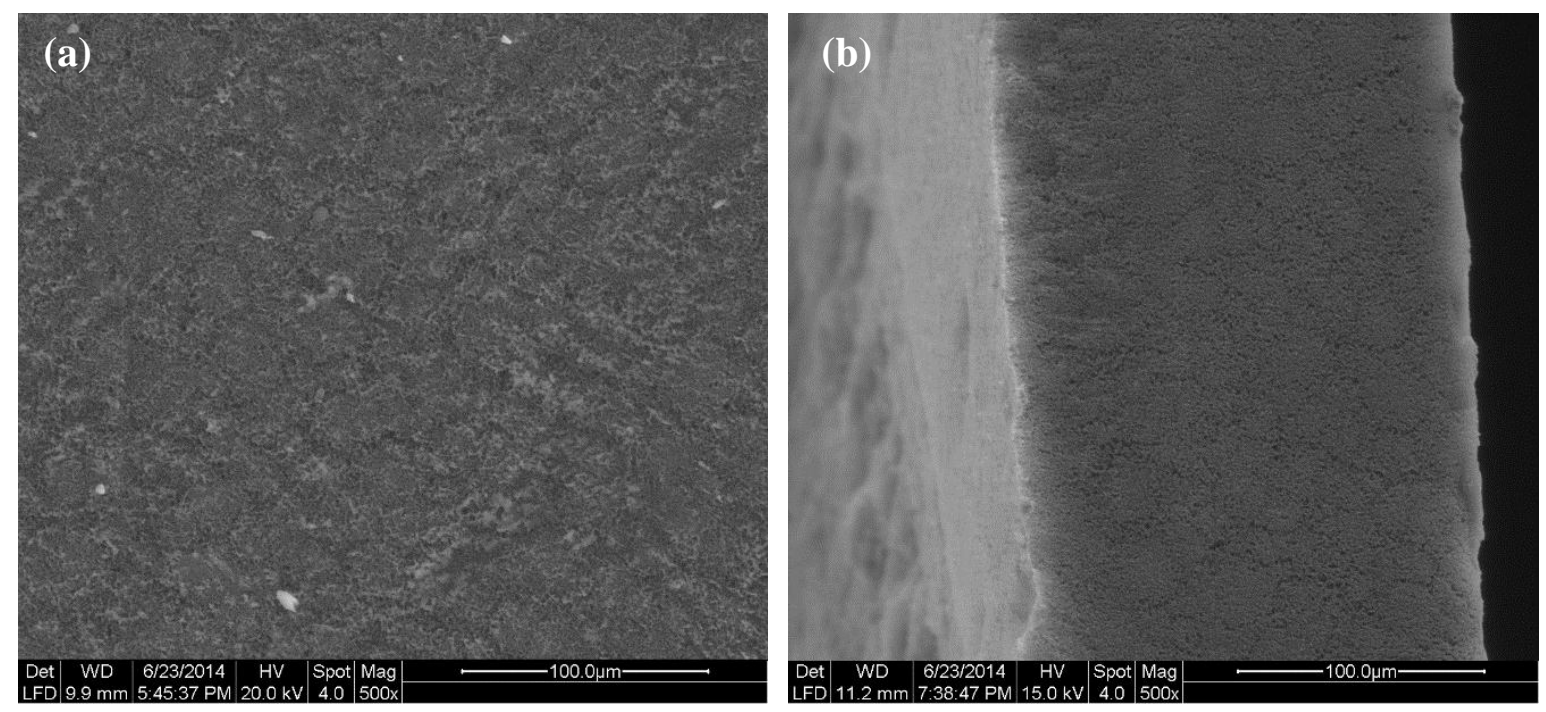

Fig. 15. (a) Surface and (b) cross-section SEM micrographs of membrane used for multiple concentration cycles with temperature reversal using GSL brine as feed, constant $T_{\mathrm{f}}$ of $50{ }^{\circ} \mathrm{C}$, constant $T_{\mathrm{d}}$ of $30^{\circ} \mathrm{C}$ using Cell 2 . For each concentration cycle the brine was concentrated until $8 \%$ recovery before dilution, followed by 5 minutes of operation with GSL brine at constant $T_{\mathrm{f}}$ of $20{ }^{\circ} \mathrm{C}$ and constant $T_{\mathrm{d}}$ of $30{ }^{\circ} \mathrm{C}$ before beginning the next concentration cycle. Both feed and distillate flow rates were constant $1.6 \mathrm{~L} \mathrm{~min}^{-1}$ in co-current configuration. Feed side of the membrane is towards the left in image (b). 


\section{Conclusions}

This study investigated the effects of scaling and fouling on performance and durability of DCMD for the concentration of a hypersaline brine collected from the North Arm of the Great Salt Lake containing sparingly soluble salts and natural organic matter. Impacts on water flux, thermal efficiency, and salt rejection were observed that resulted from reversible effects occurring only at high concentration factors, and irreversible effects that were independent of concentration.

At the highest concentration factors, $\mathrm{NaCl}$ crystallization on the membrane surface caused rapid decline in performance and termination of the process. However, the $\mathrm{NaCl}$ crystal layer easily dissolved and performance was fully restored upon dilution when the difference between the feed and distillate temperature $(\Delta T)$ was not greater than $20^{\circ} \mathrm{C}$. At higher $\Delta T$ operation, $\mathrm{NaCl}$ crystallization damaged the internal pore structure of the membranes and progressively increased wetting tendency with each concentration cycle.

Theoretical calculation of the scaling tendencies of various salts present in the GSL brine was an effective method for predicting the concentration limit imposed by $\mathrm{NaCl}$ crystallization, and terminating the process before this concentration was reached, preventing damage to the membrane structure. This approach was ineffective for predicting scaling behavior of sparingly soluble salts, which did not precipitate on the membrane surface in a manner expected based on theoretical solubility in the bulk solution.

The effects of $\mathrm{NaCl}$ crystallization on performance and salt rejection were similar for both pure $\mathrm{NaCl}$ solutions and the GSL brine. However, additional effects were observed during concentration of the GSL brine that caused a progressive decline in water flux, thermal efficiency, and salt rejection that were not restored upon dilution to the original concentration. These effects were determined to be predominantly a result of fouling by $\mathrm{NOM}-\mathrm{Mg}^{2+}$ complexation.

Operation at reduced water recovery to keep the $\mathrm{NaCl}$ concentration below saturation was effective at preventing $\mathrm{NaCl}$ crystallization and damage to internal pore structure during GSL brine concentration. Performance decline and loss of salt rejection resulting from other effects were mitigated by periodic operation with higher distillate temperature than feed temperature, reversing the direction of the driving force of the DCMD process and direction of water flow. However, the approach was time and energy intensive, requiring 20-40 minutes of reverse 
operation between each concentration cycle to completely prevent performance decline and maintain high salt rejection.

\section{Acknowledgements}

The authors would like to thank the National Science Foundation under agreement CBET1236846 for funding this research. The authors would also like to thank the Edna Bailey Sussman Foundation for additional financial support of this research. Special thanks to Dr. Corey Milne, Dr. Dan Pannell, and Jerry Poe of Compass Minerals for providing water samples from the Great Salt Lake and technical support, and to the GE Corporation for providing the membranes used in this research.

\section{References}

[1] N. Ghaffour, T.M. Missimer, G.L. Amy, Technical review and evaluation of the economics of water desalination: Current and future challenges for better water supply sustainability, Desalination, 309 (2013) 197-207.

[2] A.M.O. Mohamed, M. Maraqa, J. Al Handhaly, Impact of land disposal of reject brine from desalination plants on soil and groundwater, Desalination, 182 (2005) 411-433.

[3] J.A. Epstein, Utilization of the dead sea minerals (a review), Hydrometallurgy, 2 (1976) 1-10.

[4] D.L. Gallup, Geochemistry of geothermal fluids and well scales, and potential for mineral recovery, Ore Geology Reviews, 12 (1998) 225-236.

[5] A. Maimoni, Minerals recovery from salton sea geothermal brines: a literature review and proposed cementation process, Geothermics, 11 (1982) 239-258.

[6] H.H. Werner, Contribution to the mineral extraction from supersaturated geothermal brines Salton Sea Area, California, Geothermics, 2, Part 2 (1970) 1651-1655.

[7] M. Ahmed, A. Arakel, D. Hoey, M.R. Thumarukudy, M.F.A. Goosen, M. Al-Haddabi, A. AlBelushi, Feasibility of salt production from inland RO desalination plant reject brine: A case study, Desalination, 158 (2003) 109-117.

[8] A.H. Hamzaoui, A. M'Nif, H. Hammi, R. Rokbani, Contribution to the lithium recovery from brine, Desalination, 158 (2003) 221-224.

[9] J.A. Epstein, E.M. Feist, J. Zmora, Y. Marcus, Extraction of lithium from the dead sea, Hydrometallurgy, 6 (1981) 269-275.

[10] M. Petersková, C. Valderrama, O. Gibert, J.L. Cortina, Extraction of valuable metal ions $(\mathrm{Cs}, \mathrm{Rb}, \mathrm{Li}, \mathrm{U})$ from reverse osmosis concentrate using selective sorbents, Desalination, 286 (2012) 316-323. 
[11] H. Bukowsky, E. Uhlemann, D. Steinborn, The recovery of pure lithium chloride from "brines" containing higher contents of calcium chloride and magnesium chloride, Hydrometallurgy, 27 (1991) 317-325.

[12] O.J. Morin, Design and Operating Comparison of Msf and Med Systems, Desalination, 93 (1993) 69-109.

[13] R. Sheikholeslami, Assessment of the scaling potential for sparingly soluble salts in RO and NF units, Desalination, 167 (2004) 247-256.

[14] T. Koo, Y.J. Lee, R. Sheikholeslami, Silica fouling and cleaning of reverse osmosis membranes, Desalination, 139 (2001) 43-56.

[15] K.W. Lawson, D.R. Lloyd, Membrane distillation, Journal of Membrane Science, 124 (1997) 1-25.

[16] Y.B. Yun, R.Y. Ma, W.Z. Zhang, A.G. Fane, J.D. Li, Direct contact membrane distillation mechanism for high concentration NaCl solutions, Desalination, 188 (2006) 251-262.

[17] F. He, J. Gilron, K.K. Sirkar, High water recovery in direct contact membrane distillation using a series of cascades, Desalination, 323 (2013) 48-54.

[18] M. Safavi, T. Mohammadi, High-salinity water desalination using VMD, Chemical Engineering Journal, 149 (2009) 191-195.

[19] A. Alkhudhiri, N. Darwish, N. Hilal, Treatment of high salinity solutions: Application of air gap membrane distillation, Desalination, 287 (2012) 55-60.

[20] X. Ji, E. Curcio, S. Al Obaidani, G. Di Profio, E. Fontananova, E. Drioli, Membrane distillation-crystallization of seawater reverse osmosis brines, Separation and Purification Technology, 71 (2010) 76-82.

[21] C.R. Martinetti, A.E. Childress, T.Y. Cath, High recovery of concentrated RO brines using forward osmosis and membrane distillation, Journal of Membrane Science, 331 (2009) 31-39.

[22] A. Pérez-González, A.M. Urtiaga, R. Ibáñez, I. Ortiz, State of the art and review on the treatment technologies of water reverse osmosis concentrates, Water Research, 46 (2012) 267283.

[23] D. Qu, J. Wang, B. Fan, Z.K. Luan, D.Y. Hou, Study on concentrating primary reverse osmosis retentate by direct contact membrane distillation, Desalination, 247 (2009) 540-550.

[24] T.Y. Cath, Osmotically and thermally driven membrane processes for enhancement of water recovery in desalination processes, Desalination and Water Treatment, 15 (2010) 279-286.

[25] E. Drioli, E. Curcio, A. Criscuoli, G.D. Profio, Integrated system for recovery of CaCO3, $\mathrm{NaCl}$ and $\mathrm{MgSO} 4 \cdot 7 \mathrm{H} 2 \mathrm{O}$ from nanofiltration retentate, Journal of Membrane Science, 239 (2004) 27-38.

[26] E. Curcio, X. Ji, A.M. Quazi, S. Barghi, G. Di Profio, E. Fontananova, T. Macleod, E. Drioli, Hybrid nanofiltration-membrane crystallization system for the treatment of sulfate wastes, Journal of Membrane Science, 360 (2010) 493-498.

[27] F. Macedonio, E. Drioli, E. Curcio, G. Di Profio, Experimental and economical evaluation of a membrane crystallizer plant, Desalination and Water Treatment, 9 (2009) 49-53. 
[28] K.L. Hickenbottom, T.Y. Cath, Sustainable operation of membrane distillation for enhancement of mineral recovery from hypersaline solutions, Journal of Membrane Science, 454 (2014) 426-435.

[29] M. Gryta, Concentration of $\mathrm{NaCl}$ solution by membrane distillation integrated with crystallization, Separation Science and Technology, 37 (2002) 3535-3558.

[30] M. Gryta, Direct contact membrane distillation with crystallization applied to $\mathrm{NaCl}$ solutions, Chemical Papers-Chemicke Zvesti, 56 (2002) 14-19.

[31] F. Edwie, T.-S. Chung, Development of simultaneous membrane distillation-crystallization (SMDC) technology for treatment of saturated brine, Chemical Engineering Science, 98 (2013) 160-172.

[32] C.M. Tun, A.G. Fane, J.T. Matheickal, R. Sheikholeslami, Membrane distillation crystallization of concentrated salts - flux and crystal formation, Journal of Membrane Science, 257 (2005) 144-155.

[33] M. Gryta, Alkaline scaling in the membrane distillation process, Desalination, 228 (2008) 128-134.

[34] M. Gryta, Long-term performance of membrane distillation process, Journal of Membrane Science, 265 (2005) 153-159.

[35] E. Curcio, X.S. Ji, G. Di Profio, A. Sulaiman, E. Fontananova, E. Drioli, Membrane distillation operated at high seawater concentration factors: Role of the membrane on $\mathrm{CaCO} 3$ scaling in presence of humic acid, Journal of Membrane Science, 346 (2010) 263-269.

[36] L.D. Nghiem, T. Cath, A scaling mitigation approach during direct contact membrane distillation, Separation and Purification Technology, 80 (2011) 315-322.

[37] F. He, K.K. Sirkar, J. Gilron, Studies on scaling of membranes in desalination by direct contact membrane distillation: $\mathrm{CaCO} 3$ and mixed $\mathrm{CaCO} 3 / \mathrm{CaSO} 4$ systems, Chemical Engineering Science, 64 (2009) 1844-1859.

[38] J. Gilron, Y. Ladizansky, E. Korin, Silica Fouling in Direct Contact Membrane Distillation, Industrial \& Engineering Chemistry Research, 52 (2013) 10521-10529.

[39] M. Gryta, Fouling in direct contact membrane distillation process, Journal of Membrane Science, 325 (2008) 383-394.

[40] E. Guillen-Burrieza, R. Thomas, B. Mansoor, D. Johnson, N. Hilal, H. Arafat, Effect of Dry-out on the Fouling of PVDF and PTFE Membranes under Conditions Simulating Intermittent Seawater Membrane Distillation (SWMD), Journal of Membrane Science, (2013).

[41] R.W. Schofield, A.G. Fane, C.J.D. Fell, Heat and mass transfer in membrane distillation, Journal of Membrane Science, 33 (1987) 299-313.

[42] S. Al-Obaidani, E. Curcio, F. Macedonia, G. Di Profio, Al-Hinai, E. Drioli, Potential of membrane distillation in seawater desalination: Thermal efficiency sensitivity study and cost estimation, Journal of Membrane Science, 323 (2008) 85-98.

[43] F. Macedonio, E. Curcio, E. Drioli, Integrated membrane systems for seawater desalination: energetic and exergetic analysis, economic evaluation, experimental study, Desalination, 203 (2007) 260-276. 
[44] A. Alkhudhiri, N. Darwish, N. Hilal, Membrane distillation: A comprehensive review, Desalination, 287 (2012) 2-18.

[45] A.P.H.A. Andrew D Eaton, American Water Works Association, Water Environment Federation, Standard methods for the examination of water and wastewater, 21st ed., American Public Health Association (APHA), Washington, DC, USA, 2005.

[46] G. Schock, A. Miguel, Mass transfer and pressure loss in spiral wound modules, Desalination, 64 (1987) 339-352.

[47] J.L. Domagalski, W.H. Orem, H.P. Eugster, Organic geochemistry and brine composition in Great Salt, Mono, and Walker Lakes, Geochimica et Cosmochimica Acta, 53 (1989) 2857-2872.

[48] J.W. Gwynn, Great Salt Lake, Utah: Chemical and Physical Variations of the Brine and Effects of the SPRR Causeway, 1966-1996, (1998).

[49] T. Arnow, Water-Level and Water-Quality Changes in Great Salt Lake, Utah 1843-1985, (1985).

[50] R.J. Spencer, H.P. Eugster, B.F. Jones, Geochemistry of great Salt Lake, Utah II: Pleistocene-Holocene evolution, Geochimica et Cosmochimica Acta, 49 (1985) 739-747.

[51] S. Al-Jibbouri, J. Ulrich, The Influence of Impurities on Crystallization Kinetics of Sodium Chloride, Crystal Research and Technology, 36 (2001) 1365-1375.

[52] H. Langer, H. Offermann, On the Solubility of Sodium-Chloride in Water, Journal of Crystal Growth, 60 (1982) 389-392.

[53] T.G. Tripp, Production of Magnesium from Great Salt Lake, Utah, USA, Natural Resources and Environmental Issues, 15 (2009) 55.

[54] J.G. Albright, R. Mathew, D.G. Miller, J.A. Rard, Isothermal diffusion coefficients for sodium chloride-magnesium chloride-water at 25.degree.C. 1. Solute concentration ratio of 3:1, The Journal of Physical Chemistry, 93 (1989) 2176-2180.

[55] Y.-N. Wang, C.Y. Tang, Protein fouling of nanofiltration, reverse osmosis, and ultrafiltration membranes-The role of hydrodynamic conditions, solution chemistry, and membrane properties, Journal of Membrane Science, 376 (2011) 275-282.

[56] S.K. Hong, M. Elimelech, Chemical and physical aspects of natural organic matter (NOM) fouling of nanofiltration membranes, Journal of Membrane Science, 132 (1997) 159-181.

[57] C.Y. Tang, Y.-N. Kwon, J.O. Leckie, The role of foulant-foulant electrostatic interaction on limiting flux for RO and NF membranes during humic acid fouling-Theoretical basis, experimental evidence, and AFM interaction force measurement, Journal of Membrane Science, 326 (2009) 526-532.

[58] R. Sheikholeslami, H.W.K. Ong, Kinetics and thermodynamics of calcium carbonate and calcium sulfate at salinities up to $1.5 \mathrm{M}$, Desalination, 157 (2003) 217-234.

[59] S. Srisurichan, R. Jiraratananon, A.G. Fane, Humic acid fouling in the membrane distillation process, Desalination, 174 (2005) 63-72.

[60] M. Gryta, M. Tomaszewska, J. Grzechulska, A.W. Morawski, Membrane distillation of $\mathrm{NaCL}$ solution containing natural organic matter, Journal of Membrane Science, 181 (2001) 279287. 